University of Nebraska - Lincoln

DigitalCommons@University of Nebraska - Lincoln

Papers in the Earth and Atmospheric Sciences Earth and Atmospheric Sciences, Department

\title{
Aragonite loss in a cold-water coral mound: Mechanisms and implications
}

Tracy D. Frank

University of Nebraska-Lincoln, tfrank2@unl.edu

Jürgen Titschack

Friedrich-Alexander-Universität Erlangen-Nürnberg

Mieke Thierens

University College Cork, Ireland

Follow this and additional works at: https://digitalcommons.unl.edu/geosciencefacpub

Part of the Earth Sciences Commons

Frank, Tracy D.; Titschack, Jürgen; and Thierens, Mieke, "Aragonite loss in a cold-water coral mound: Mechanisms and implications" (2011). Papers in the Earth and Atmospheric Sciences. 301.

https://digitalcommons.unl.edu/geosciencefacpub/301

This Article is brought to you for free and open access by the Earth and Atmospheric Sciences, Department of at DigitalCommons@University of Nebraska - Lincoln. It has been accepted for inclusion in Papers in the Earth and Atmospheric Sciences by an authorized administrator of DigitalCommons@University of Nebraska - Lincoln. 
Published in Sedimentology 58:3 (April 2011), pp. 670-690, doi: 10.1111/j.1365-3091.2010.01178.x Copyright C) 2010 Tracy D Frank, Jürgen Titschack, and Mieke Thierens. Journal compilation (C) 2010 International Association of Sedimentologists; published by Wiley-Blackwell. Used by permission.

Submitted September 8, 2009; accepted May 24, 2010; published online July 13, 2010.

\title{
Aragonite loss in a cold-water coral mound: Mechanisms and implications
}

\author{
Tracy D Frank, ${ }^{1}$ Jürgen Titschack, ${ }^{2}$ and Mieke Thierens ${ }^{3}$ \\ 1. Department of Geosciences, University of Nebraska-Lincoln, \\ 214 Bessey Hall, Lincoln, NE 68588-0340, USA; email tfrank2@unl.edu \\ 2. GeoZentrum Nordbayern, Fachgruppe Paläoumwelt, \\ Friedrich-Alexander-Universität Erlangen-Nürnberg, Loewenichstr. 28, 91054 Erlangen, Germany \\ 3. Geology Department and Environmental Research Institute, University College Cork, \\ Lee Road, Cork, Ireland
}

\begin{abstract}
Selective dissolution of aragonitic grains is emerging as a volumetrically significant process that affects a broad range of modern carbonate settings. This study explores mechanisms and implications of aragonite loss in Challenger Mound, a giant cold-water coral (Lophelia pertusa) mound of Pleistocene age, which lies on the continental slope off southwest Ireland. A comprehensive sampling scheme allowed the integration of petrographic data with geochemical analyses of sediment and pore water. The mound remains virtually unlithified and consists of stacked, fining-upward cycles of silty coral floatstone-rudstone and bafflestone grading into wackestone. Whereas calcitic grains appear unaltered, aragonitic grains are corroded and fragmented. Aragonite dissolution is attributed to organic matter oxidation at/near the sediment-water interface and, at greater depths, to the initial stages of bacterially mediated sulfate reduction, when alkalinity production is outpaced by the generation of $\mathrm{H}^{+}$. Pore water profiles indicate that undersaturated waters are diffusing towards the mound interior from two centers of sulfate reduction: one located in the upper $10 \mathrm{~m}$ of the sediment column and a second that lies below an erosional unconformity which marks the base of the mound. Continued aragonite dissolution is expected to gradually lower the diagenetic potential of the Challenger Mound and delay lithification until deep burial, when solution-compaction processes come into play. Despite a fundamental role in predestining the final taphonomic and textural characteristics of Challenger Mound, the processes described here are expected to leave little trace in the geological record due to a lack of cementation and calcitization. Assuming that similar processes have been active throughout the Phanerozoic, results imply that the understanding of diagenetic processes in carbonate systems may be incomplete.
\end{abstract}

Keywords: aragonite, carbonate rocks, cold water, coral mound, diagenesis, pore water

\section{Introduction}

To infer depositional conditions from ancient carbonate deposits, it is necessary to figuratively peel back the veneer of diagenetic alteration to expose the primary signatures that lie beneath. The conceptual bridge between modern systems and their ancient counterparts has long been provided through diagenetic studies of exposed, photozoan-dominated Quaternary deposits of the tropical Caribbean and 
Atlantic, which formed under conditions similar to those of the present and yet have undergone diagenetic alteration in the marine and meteoric realms. These studies, summarized in James \& Choquette (1990a,b), suggested that vestiges of originally aragonitic constituents will persist in the geological record as moulds, cement-filled voids and neomorphosed grains. However, as the scope of research has expanded to include a broader range of carbonate depositional and diagenetic settings, aragonite dissolution during the earliest stages of diagenesis has emerged as a volumetrically significant process that holds significant implications for the ancient rock record (Melim et al., 1995, 2002; Sanders, 2003, 2004; Wright \& Cherns, 2004, 2008; James et al., 2005; Cherns \& Wright, 2009).

Selective removal of aragonitic components has been documented across a spectrum of modern carbonate depositional settings that lie above the aragonite lysocline, including cool-water settings (Brachert \& Dullo, 2000; James et al., 2005) and the interiors (Walter \& Burton, 1990; Walter et al., 1993, 2007; Ku et al., 1999) and margins (Malone et al., 2001; Melim et al., 2002; Schwarz \& Rendle-Buhring, 2005) of tropical platform systems that serve as key modern analogues for ancient deposits. In a volumetrically significant process, the resulting reduction of diagenetic potential should impact patterns of alteration during deep burial and/or subaerial exposure and, ultimately, produce rocks that could erroneously be perceived as accumulations of calcitic assemblages (Wright \& Cherns, 2004; James et al., 2005; Cherns \& Wright, 2009), such as those typical of cool-water carbonate settings (James, 1997). Such possibilities highlight the need for further investigation of the mechanisms, magnitudes and signatures of early diagenetic aragonite loss in a range of modern settings.

This study presents the results of an investigation of diagenetic processes affecting Challenger Mound, an aragonite-bearing, cold-water coral mound of Pleistocene age that was drilled during Expedition 307 of the Integrated Ocean Drilling Program (IODP). The site was chosen for study based on several factors. Challenger Mound lies within a zone of prolific cold-water coral mound development in the northeastern Atlantic, which has served as the focus of numerous scientific surveys. As such, the geological and oceanographic setting is well-constrained. Because the mound has neither undergone exposure nor entered the deep burial realm (Ferdelman et al., 2005; Kano et al., 2007), early diagenetic processes may be studied in isolation and without complications brought about by overprinting during later stages of diagenesis. Finally, the comprehensive sampling and analytical protocol of the IODP allows the integration of information derived from petrographic study and geochemical analysis of both sediment and pore water (Ferdelman et al., 2005). The aims of this investigation are to: (i) document the nature and distribution of aragonite dissolution in Challenger Mound; (ii) ascertain the conditions that promote aragonite dissolution; (iii) assess the loss of diagenetic potential on the post-depositional development of Challenger Mound; and (iv) explore implications for the ancient rock record.

\section{Background}

Challenger Mound, the drilling target for IODP Expedition 307, is one of ca 1000 cold-water coral mounds that occur along the slope of the Porcupine Seabight (Figure 1A) off south-west Ireland (Huvenne et al., 2003). The mounds, which lie in water depths of 600 to $1000 \mathrm{~m}$ and above the aragonite lysocline (Berger, 1978; Orr et al., 2005), are elongate, semi-conical structures that attain heights up to $200 \mathrm{~m}$ (De Mol et al., 2002). Whereas some mounds support living thickets of cold-water corals, many, including Challenger Mound, are currently inactive and blanketed by coral rubble and, in some cases, siliciclastic contourite deposits (De Mol et al., 2002; Van Rooij et al., 2003). The dominant coral is the aragonitic azooxanthellate species Lophelia pertusa. The concentration of cold-water coral communities along the Irish Shelf has been attributed to a combination of factors, which include the presence of hard substrates suitable for colonization, current systems that impede sediment accumulation and sufficient food availability (Freiwald \& Roberts, 2005). Seismic profiles and drilling in the area of Challenger Mound show that mounds initiated atop a regional-scale erosional surface developed in sandy, sometimes glauconitic siltstone, which has been assigned a late Miocene to late Pliocene age (Kenyon et al., 2003; Van Weering et al., 2003; Kano et al., 2007; Van Rooij et al., 2009). Thick contourite deposits attest to the presence of strong bottom currents (Van Rooij et al., 2003), important in the formation of nepheloid layers that supply food particulates to the mounds (Mienis et al., 2007). High surface productivity in the region is attributed to complex interactions between sub-surface topography and current systems that enhance upwelling of 


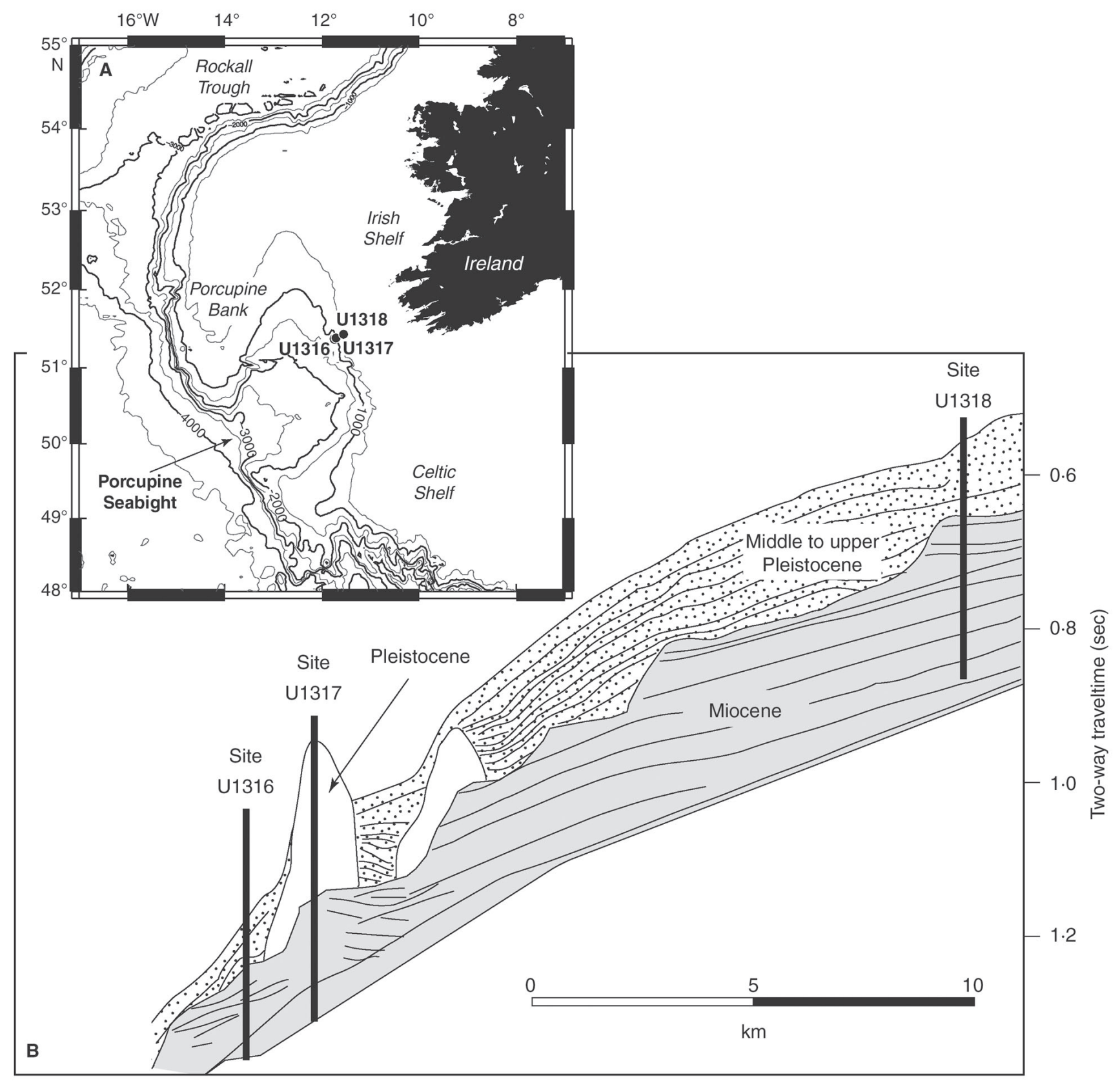

Figure 1. (A) Location map of Porcupine Seabight and IODP Expedition 307 operations area created using gridded relief data from the US National Geophysical Data Center. (B) Interpretation of seismic profile P980521 in the vicinity of Challenger Mound (after De Mol et al., 2002). Also shown are the locations of Sites U1316 to U1318. Ages are from Kano et al. (2007).

nutrient-rich waters along the shelf break while also limiting shelf-basin exchange (White et al., 2005). The end result of these interactions is the retention of cool (sea floor temperatures $\mathrm{ca} 10^{\circ} \mathrm{C}$ ), nutrient-rich bottom water over the mound province (White et al., 1998).

During IODP Expedition 307, three sites were drilled along an east-west oriented depth transect (Figure 1B) that extended from a water depth of $423 \mathrm{~m}$ at Site U1318 downslope to $965 \mathrm{~m}$ at Site U1316. Challenger Mound, the focus of Site U1317, lies in the central portion of the transect at depths of 781 to $815 \mathrm{~m}$. Sites U1316 and U1318 were drilled into siliciclastic drift deposits that provide a record of premound, syn-mound and post-mound sedimentation. Both sites penetrate two major units that are visible in seismic profiles (Figure 1B; Ferdelman et al., 2006; Kano et al., 2007; Huvenne et al., in press). The upper unit consists of poorly fossiliferous, interlaminated and admixed mud and fine sand with outsized clasts (ice-rafted debris) and is of middle to upper Pleisto- 
cene age. At Site U1316, the basal 2 to $4 \mathrm{~m}$ of the upper unit contains abundant coral debris, interpreted to record off-mound transport. Here, upper Pliocene to Pleistocene strata unconformably overlie a suite of poorly to moderately fossiliferous, admixed and interbedded clay, silt and fine, sometimes glauconitic and silty, sand of upper Miocene age.

Challenger Mound was fully penetrated four times, with cores taken from the top of the mound (Hole U1317E) and along its north-western uppermost flank (Holes U1317A to U1317C; Figure 2). Hole U1317D was drilled to recover sub-mound strata only. The mound remains almost entirely unlithified and consists of unlithified silty coral floatstone-rudstone and bafflestone with minor wackestone (Figure $3 \mathrm{~A}$ and $\mathrm{B}$ ). Facies are commonly arranged in a cyclic manner, with coral floatstone-rudstone and bafflestone grading upward into wackestone (Ferdelman et al., 2005). Cycles are often separated by erosional surfaces and/or burrowed surfaces (Figure 3C). In Hole U1317A, some wackestones that form the tops of fining-upward cycles are lightly lithified; such lithification was not observed in other holes. The base of the mound is marked by a sharp, erosional surface developed atop Miocene-age strata (Figure 3D) that were also penetrated in the lower portions of Sites U1316 and U1318.

Biostratigraphic, magnetostratigraphic and Sr isotopic data indicate that Challenger Mound formed during the last 2.7 Myr (Kano et al., 2007; Foubert \& Henriet, 2009). A significant hiatus, 1.6 to $0.8 \mathrm{Ma}$, at 22.98 meters below sea floor (mbsf) separates an expanded lower mound section marked by relatively high accumulation rates (Unit M1 of Titschack et al., 2009) from a condensed sequence (Unit M2 of Titschack et al., 2009) in the upper part of the mound. Mound growth ended ca 0.5 Ma (Kano et al., 2007).

\section{Methods}

\section{Sediment petrography and geochemistry}

Samples for petrographic and geochemical analysis were taken at 5 to $10 \mathrm{~m}$ intervals from Holes U1317A, D and E. Thin sections of resin-impregnated core sections and grain mounts of the sandgravel size fraction were examined using standard petrographic and cathodoluminescence (CL) microscopy (Nuclide ELM-2A luminoscope, 15 to $30 \mathrm{kV}$, 0.8 to 0.9 milliamps beam current, 120 mTorr vac- uum; Nuclide Corporation, Acton, MA, USA). Broken surfaces of selected dry sediment samples were analyzed under the scanning electron microscope (SEM). A Preservation Index (PI) was developed to quantify stratigraphic variations in the state of coral preservation. Preservation Index values range from 0 to 4 , with 0 corresponding to excellent preservation (no evidence of corrosion or breakage) and 4 to very poor preservation, manifest as complete dissolution of septae and disintegration of the theca into silt-sized pieces.

Carbon and oxygen isotope compositions were determined on skeletal separates (i.e. coral fragments) from Hole U1317E and the calcareous component of the mud size fraction in Holes U1317A, D and E. Prior to analysis, volatile contaminants were removed by roasting the samples under vacuum at $380{ }^{\circ} \mathrm{C}$ for $1 \mathrm{~h}$. Samples were then reacted at $73{ }^{\circ} \mathrm{C}$ with anhydrous phosphoric acid in individual reaction vessels of an online, automated Kiel III device coupled to a ThermoFinnigan MAT 253 mass spectrometer (Thermo Fisher Scientific, Waltham, MA, USA) in the W. M. Keck Paleoenvironmental and Environmental Stable Isotope Laboratory (KPESIL) in the Department of Geology at the University of Kansas. Oxygen isotope ratios were corrected for ${ }^{17} \mathrm{O}$ contribution (Craig, 1957). Values are reported in permil $(\%)$ relative to the Vienna Pee Dee belemnite (VPDB) standard. Precision is better than $0.05 \%$ for $\delta^{18} \mathrm{O}$ and $\delta^{13} \mathrm{C}$ values, and was monitored though daily analyses of National Bureau of Standards (NBS) and other in-house carbonate standards.

Concentrations and stable isotope compositions of organic carbon $\left(\mathrm{C}_{\text {org }}\right)$ and total nitrogen $\left(\mathrm{N}_{\text {tot }}\right)$ were carried out on bulk samples of sedimentary organic matter from Hole U1317E. In preparation for analysis, sediment samples were dried and powdered. A ca $5 \mathrm{~g}$ split was treated with $1 \mathrm{~m} \mathrm{HCl}$ and allowed to react for 24 to $48 \mathrm{~h}$. The acid solution was then decanted and the $\mathrm{pH}$ measured. This process was repeated until the acid solution reached a $\mathrm{pH}<2$, indicating complete removal of inorganic carbon. Samples were then rinsed in deionized water, filtered and dried overnight in a $50{ }^{\circ} \mathrm{C}$ oven. The $\mathrm{C}_{\text {org }}$ and $\mathrm{N}_{\text {tot }}$ determinations were made using a Costech Instruments Element Analyzer (Costech Analytical Technologies Inc., Valencia, CA, USA) connected to a ThermoFinnigan MAT 253 mass spectrometer in KPESIL at the University of Kansas. Values for $\delta^{13} C_{\text {org }}$ are reported in permil (\%o) relative to the VPDB standard. Repeated analyses of Montana Soil (NIST Ref Mat. 2711) and a 


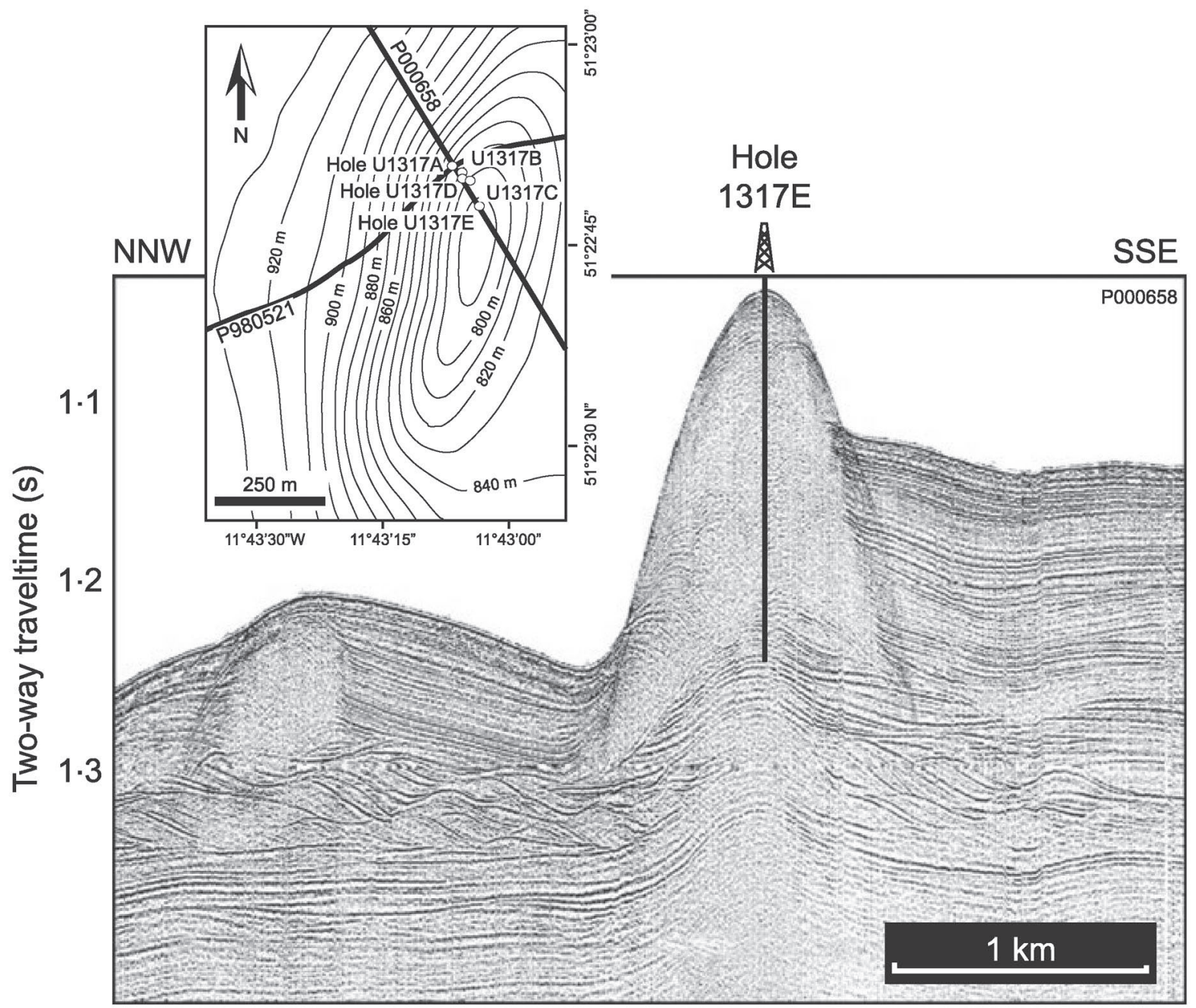

Figure 2. High-resolution seismic profile P000658 through Challenger Mound. The inset shows orientations of seismic profiles P000658 and P980521 (Figure 1B), mound bathymetry and locations of Holes U1317A to U1317E. Note that only sub-mound strata were recovered from Hole U1317D. Modified from Henriet et al. (2002).

calibrated Yeast standard show precision for $\delta^{13} C_{\text {org }}$ to be better than $\pm 0.42 \%$.

The mineralogy of the sediment matrix through Challenger Mound (0.31 to 158.11 mbsf in Hole U1317E) was determined by X-ray diffraction (XRD). Samples were prepared according to the standardized laboratory procedure of the mineralogical laboratory at GeoZentrum Nordbayern. Dried samples were powdered and sieved through a $25 \mu \mathrm{m}$ mesh to ensure uniformly small particle size. X-ray data were collected using a Siemens D5000 diffractometer (Bragg-Brentano geometry; Siemens AG, Munich, Germany) equipped with a $\mathrm{Cu}$ radiation source (Generator: $30 \mathrm{~mA}, 40 \mathrm{kV}$ ), $2.3^{\circ}$ soller slits, $0.5^{\circ}$ fixed divergence slits, a secondary graphite monochromator, $0.2 \mathrm{~mm}$ detector slit and a scintillation counter detector. An angular range of $5^{\circ}$ to $70^{\circ} 2 \theta$ was measured with a step size of $0.02^{\circ}$ and 2 sec counting time per step. Phases were quantified using the Rietveld refinement software topas 3.0 (Coelho Software, Brisbane, Australia) with fundamental parameter approach. Further details and tabulated results are presented in Titschack et al. (2009).

\section{Pore water geochemistry}

Pore water samples were extruded from wholeround sections of core that were collected from Holes U1317A (1.40 to $136.00 \mathrm{mbsf}$ ), U1317D (129.95 to $266.01 \mathrm{mbsf}$ ) and U1317E (1.40 to $33.10 \mathrm{mbsf}$ ). A sampling density of every 5 to $10 \mathrm{~m}$ ensured sample coverage throughout Site U1317. Samples were placed in a titanium squeezer modified after Manheim \& Sayles (1974). Pore water was passed through a prewashed Whatman 1 filter fitted above a titanium screen, fil- 
Figure 3. Photographs showing variation in lithologies and coral preservation encountered in Challenger Mound. (A) Unlithified coral floatstone-rudstone in Hole U1317A-1H-1, 109 to $128 \mathrm{~cm}$ (1.09 to $1.28 \mathrm{mbsf})$. Skeletal debris is fragmented coral. Dark grey, sand-sized grains are lithoclasts interpreted as ice-rafted debris. (B) Unlithified coral floatstone in Hole 1317C-2H-4, 104 to $122 \mathrm{~cm}$ (5.49 to $5.65 \mathrm{mbsf})$. Coral skeletons are chalky in appearance but remain largely intact. (C) Erosional, burrowed contact between lightly lithified wackestone with sparse, fragmented corals and overlying unlithified coral floatstone-rudstone with clasts of underlying wackestone (arrows) and abundant, dispersed coral fragments in Hole U1317A-7H-1, 113 to $133 \mathrm{~cm}$ (55.13 to $55.33 \mathrm{mbsf}$ ). (D) Hole U1317A$14 \mathrm{H}-7,0$ to $20 \mathrm{~cm}$ (130.0 to $130.20 \mathrm{mbsf}$ ), showing sharp, erosional contact at $c a$ 130.10 mbsf between lithified, poorly fossiliferous siltstone (Miocene submound facies) and overlying unlithified silty wackestone-packstone (Pleistocene mound facies). Many voids contain fragmented remains of corals (arrows), indicating that they represent mouldic porosity after coral.
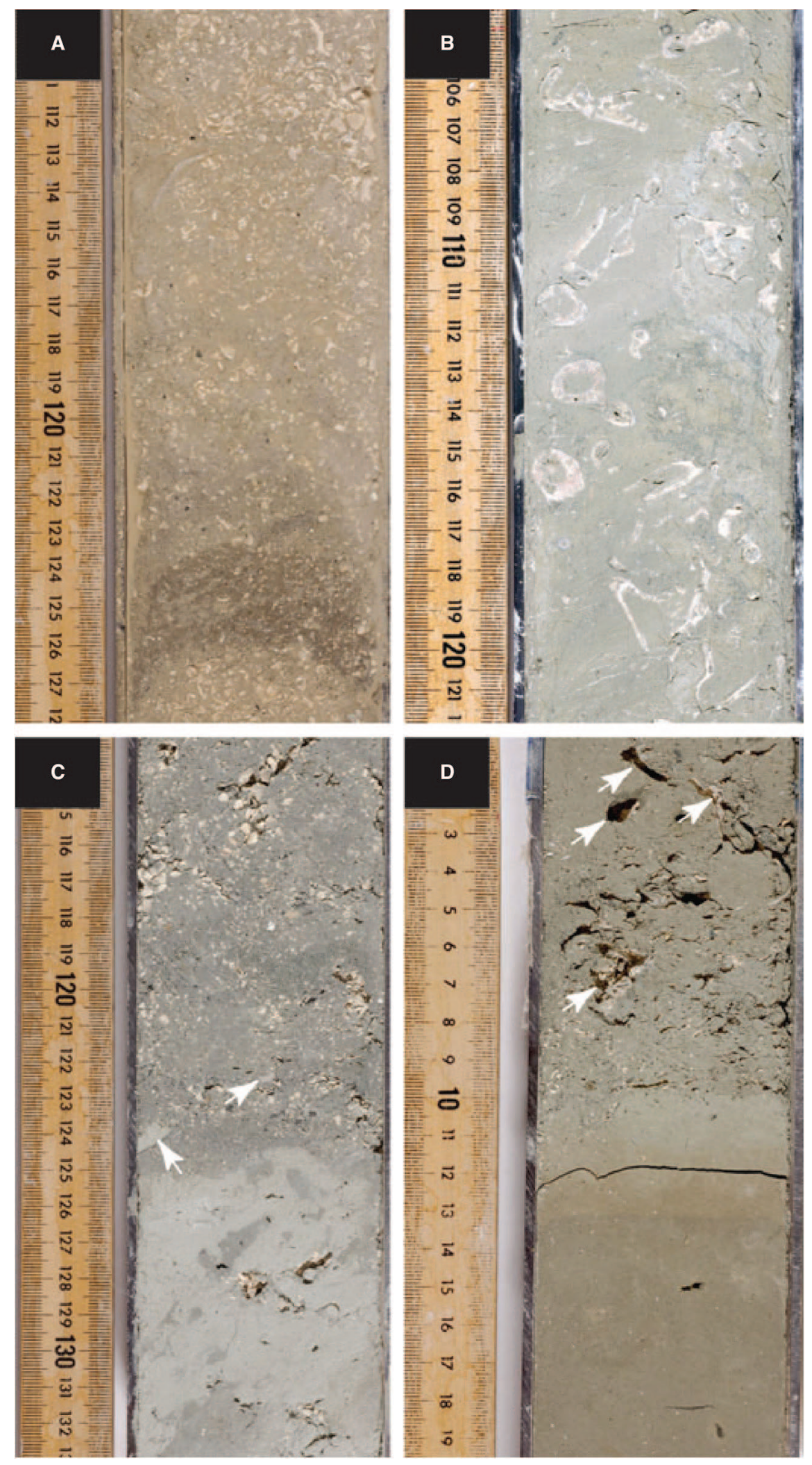

tered through a $0.45 \mu \mathrm{m}$ Gelman polysulfone disposable filter, and subsequently extruded into a precleaned $(10 \% \mathrm{HCl}) 50 \mathrm{~mL}$ plastic syringe attached to the bottom of the squeezer assembly.
Analyses of alkalinity and major ions $\left(\mathrm{Ca}^{2+}, \mathrm{Mg}^{2+}\right.$, $\mathrm{Sr}^{2+}$ and $\mathrm{SO}_{4}{ }^{2-}$ ) in pore water samples were carried out on board the JOIDES Resolution using standard IODP protocol (Gieskes et al., 1991; Murray et al., 

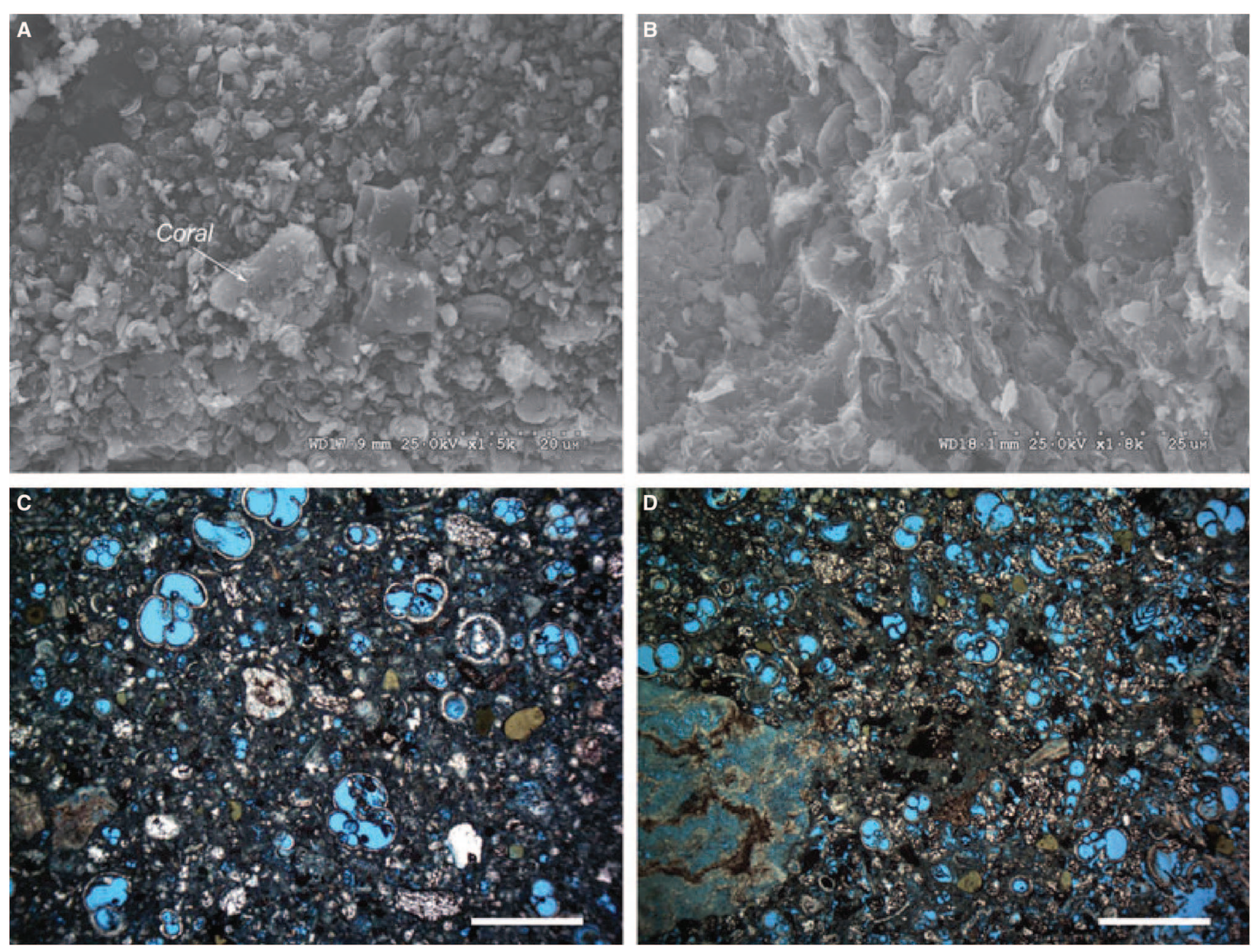

Figure 4. Photomicrographs of coral floatstone-rudstone matrix in Hole 1317E. SEM images of sample from (A) 8.88 mbsf and (B) 99.00 mbsf show that the matrix is dominated by admixtures of coccolith elements and terrigenous mud (silt and clay). Also present are silt-sized fragments of coral. Plane-polarized light images of thin sections of blue resin-impregnated samples from (C) $13.38 \mathrm{mbsf}$, scale bar $500 \mu \mathrm{m}$, and (D) $146.43 \mathrm{mbsf}$, scale bar $500 \mu \mathrm{m}$, show that planktonic foraminifera and glauconite grains are common matrix elements in the silt to fine sand size fraction.

2000). The carbon isotope composition of dissolved inorganic carbon $\left(\delta^{13} C_{\text {DIC }}\right)$ was determined in the Environmental Isotope Laboratory (EIL) at the University of Arizona in Phoenix, AZ, USA, using an automated headspace sampler (Finnigan GasBench; Thermo Fisher Scientific) connected to a continuousflow gas-ratio mass spectrometer (Finnigan Delta PlusXL; Thermo Fisher Scientific, Waltham, MA, USA). To prevent microbial growth, samples were inoculated with ca $10 \mathrm{mg}$ of mercuric chloride $(\mathrm{HgCl})$ and stored at 4 to $10{ }^{\circ} \mathrm{C}$ until analysis. At EIL, samples were acidified with concentrated phosphoric acid and allowed to degas for at least $30 \mathrm{~min}$. Carbon isotope ratios are reported in parts per thousand (\%o) relative to VPDB. Precision is $\pm 0.2 \%$, as monitored through multiple analyses of an in-house sodiumbicarbonate standard solution that was calibrated against NBS 18 and 19.
Concentrations of dissolved methane were monitored at intervals of 5 to $10 \mathrm{~m}$ in Holes U1317A and D. Immediately after each coring run, a sediment sample was collected from the freshly exposed end of a core section using an open-ended plastic syringe. After sampling, $3 \mathrm{~cm}^{3}$ of sediment was extruded into a $20 \mathrm{~mL}$ vial containing $5 \mathrm{~mL}$ of $1 \mathrm{~m}$ $\mathrm{NaOH}$. The vial was immediately capped with a silicone/PTFE septum and aluminum crimp cap. After vigorous manual shaking for $2 \mathrm{~min}$, the vials were shaken automatically for an additional hour and subsequently left to stand for at least $23 \mathrm{~h}$ at room temperature prior to analysis using a Hewlett Packard 5890 II Plus gas chromatograph (Hewlett Packard, Palo Alto, CA, USA).

Saturation indices for aragonite and calcite in the pore water system were estimated using program $\mathrm{CO}$ 2SYS developed by Pierrot et al. (2006) for the $\mathrm{CO}_{2}$ sys- 

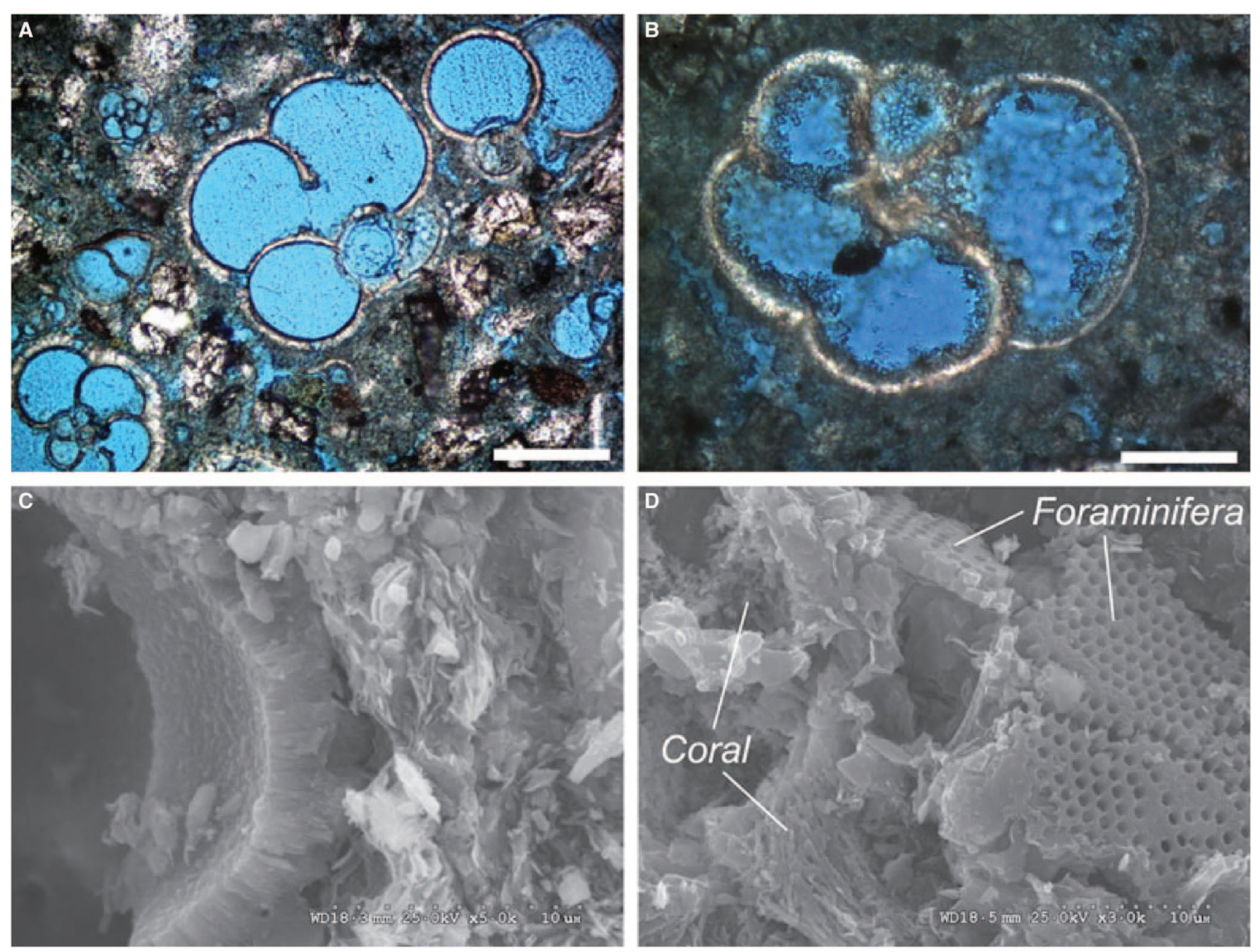

Figure 5. Photomicrographs illustrating the preservation of primary intraparticle pore space and lack of cement overgrowths in mound sediments (Hole 1317E). (A) Photomicrograph of well-preserved planktonic foraminifera with intact intraparticle pore space under plane-polarized light (146.43 mbsf). Scale bar is $100 \mu \mathrm{m}$. Pore space is filled with blue epoxy resin. (B) Well-preserved planktonic foraminifer with incipient bladed to granular cement in intraparticle pore space under plane-polarized light (32.38 mbsf). Scale bar is $50 \mu \mathrm{m}$. Pore space is filled with blue epoxy resin. (C) SEM image showing well-preserved planktonic foraminifer (132.43 mbsf). (D) SEM image showing well-preserved foraminifer chamber walls and etched coral fragments (157.19 mbsf).

tem in sea water. The program uses two of the four measurable parameters of the $\mathrm{CO}_{2}$ system, in the present case total alkalinity and DIC measured in pore water, to calculate the other two parameters at a given set of temperature and pressure conditions. The calculation methodology is that used by Takahashi et al. (1982) in association with the GEOSECS expedition.

\section{Results}

\section{Petrography}

Petrographic examination shows that the matrix consists mainly of admixtures of quartz silt and clay (mainly illite, kaolinite and chlorite), well-preserved foraminifera and coccolith elements, and coral frag- ments (Figure 4), along with lesser amounts of siliceous sponge spicules, radiolarians and fragments of other calcareous benthos. Glauconite (Figure 4, C \& D), framboidal pyrite and phosphate are also present in minor amounts, together generally comprising $<6 \%$ of the sediment volume (see also Léonide et al., 2009). With the exception of light, patchy cementation in some wackestones of Hole U1317A, intraparticle cement is absent (Figures 4 \& 5). Where present, cement overgrowths are small $(<5 \mu \mathrm{m})$ equant-bladed crystals that are irregularly distributed. Intraparticle cement occurs rarely as thin (5 to $10 \mu \mathrm{m})$ rims of equant-bladed calcite in foraminifer chambers (for example, Figure 5B). Calcitic allochems, including coccolith elements (Figure 4, A \& B), foraminifera (Figures 4C, 4D, 5A, \& 5B) and echinoid fragments, appear unaltered and show no signs of either disso- 

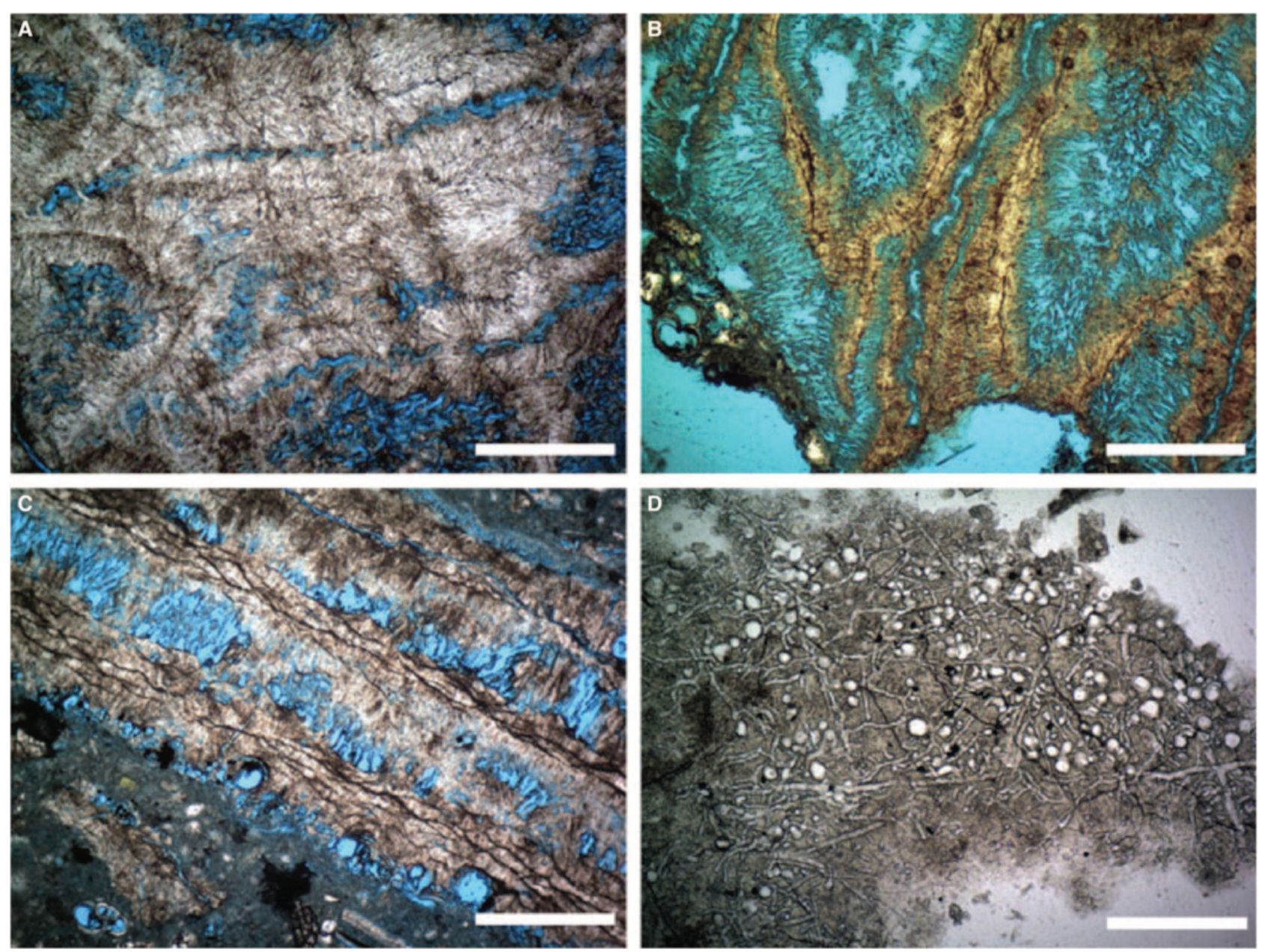

Figure 6. Plane-polarized light images of Lophelia pertusa fragments in Hole 1317E. Scale bars are $250 \mu \mathrm{m}$. (A) to (C) Fabric selective dissolution of coral fragments at (A) 13.38 mbsf, (B) 27.88 mbsf and (C) 108.45 mbsf. Pore space is filled with blue resin. (D) Unfilled microbores into grain surface, $18.38 \mathrm{mbsf}$.

lution or recrystallization. Aragonitic allochems, in particular corals, show signs of corrosion and commonly are fragmented (Figure 6). Cathodoluminescence examination revealed that, with the exception of a few porcelaneous foraminifera that appear otherwise well-preserved, all carbonate components are nonluminescent.

\section{Sediment geochemistry}

The XRD results from Hole U1317E show that the carbonate fraction of the mound matrix varies between $c a 20$ and $70 \mathrm{wt} \% \mathrm{CaCO}_{3}$ and consists primarily of low-Mg calcite (12 to $64 \mathrm{wt} \%$ ) and aragonite ( $c a$ 33 to $40 \mathrm{wt} \%$ ) with minor amounts of dolomite (average $2 \mathrm{wt} \%)$. High-Mg calcite concentrations were below the detection limit. The remainder of the matrix consists largely of quartz silt and clay (see Léonide et al., 2009; Titschack et al., 2009) classed here as terrigenous mud (Figure $7 \mathrm{~B}$ ).
Stable isotopic compositions of carbonate materials are summarized in Table 1 and Figure 7, C \& D. The $\delta^{18} \mathrm{O}$ values of bulk carbonate in the sediment matrix average $+1.5 \pm 1.1 \%$ o through the mound and shift to lower and more uniform values $(-0.1 \pm 0.4 \%$ o) in sub-mound facies. The $\delta^{13} \mathrm{C}$ values of the matrix carbonate show an opposing trend, with the mound matrix having lower values $(-2.0 \pm 2.0 \%$ ) and the sub-mound matrix having higher and more uniform values $(+1.3 \pm 0.5 \%$ o $)$. The $\delta^{18} \mathrm{O}(+0.6 \pm 1.0 \%$ o $)$ and $\delta^{13} \mathrm{C}$ $(-5.6 \pm 2.0 \%)$ values of coral aragonite are significantly lower than values derived from matrix carbonate. These values are consistent with those measured on living specimens of L. pertusa from the Rockall Bank, as shown in Figure 7, C \& D (Blamart et al., 2005). Concentrations of organic matter throughout the mound average $0.6 \pm 0.1 \mathrm{wt} \%$ (Table 2). The $\delta^{13} \mathrm{C}$ $(-22.6 \pm 1.0 \%)$ and $C_{\text {org }} / N_{\text {tot }}(7.9 \pm 2.0)$ values (Figure 7, E \& F) are consistent with the compositional range of marine organic matter (Meyers, 1997). These 


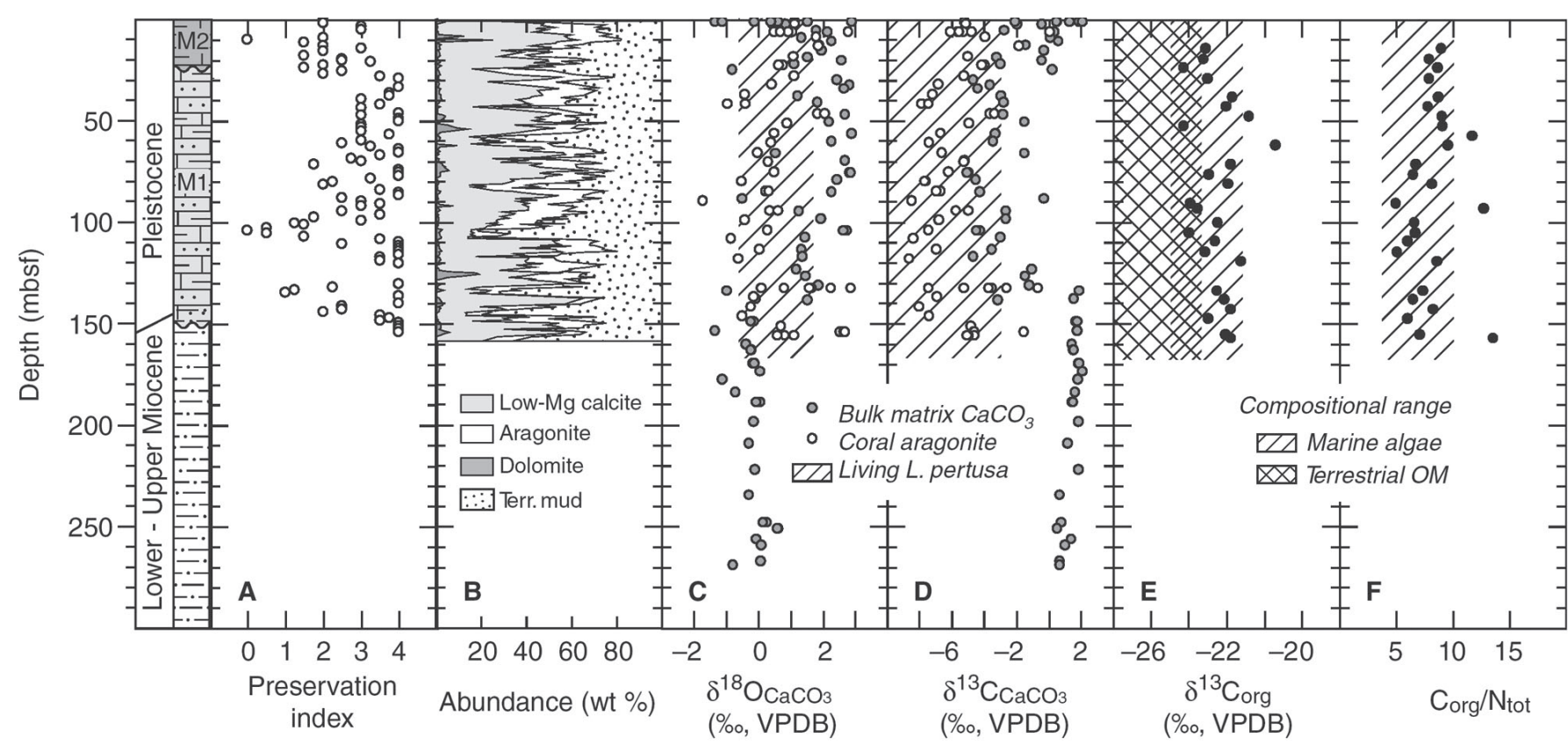

Figure 7. Overview of sediment petrography and geochemistry at Site U1317. (A) Preservation index $(0=$ excellent; $1=$ very good; 2 = good; 3 = poor; 4 = very poor). (B) Mineralogy (Hole U1317E) determined via XRD. (C) and (D) $\delta^{18} \mathrm{O}$ and $\delta^{13} \mathrm{C}$ values of bulk matrix carbonate (Holes U1317A, D and E) and coral aragonite (Hole U1317E). Ranges of $\delta^{18} \mathrm{O}$ and $\delta^{13} \mathrm{C}$ values of living Lophelia pertusa from Blamart et al. (2005) are shown for reference. (E) and (F) $\delta^{13} \mathrm{C}$ values and $\mathrm{C}_{\text {org }} / \mathrm{N}_{\text {tot }}$ ratios of bulk organic matter (Hole 1317E). Compositional ranges of marine algae and terrestrial organic matter from Meyers (1997) are shown for reference. Also shown is a generalized lithological column through Miocene sandy siltstone (sub-mound facies) and Pleistocene silty coral floatstone-rudstone and bafflestone (mound facies), subdivided into units M1 (mound base to 22.98 mbsf) and M2 (22.98 to 0 mbsf). Units M1 and M2 are underlain by erosional unconformities.

data are consistent with hydrogen index measurements of Léonide et al. (2009), which also suggest that organic matter is predominantly of marine origin.

\section{Pore water geochemistry}

Results of pore water geochemical analyses are provided in Figure 8. Tabulated data are available in Ferdelman et al. (2005) and Frank (2009). The $\mathrm{Ca}^{2+}$ data describe complex downcore trends (Figure 8A). Within lithological Unit M2, data from Holes U1317A and U1317E show disparate trends, with concentrations increasing slightly in Hole U1317A while decreasing by $c a 2 \mathrm{~mm}$ in the upper $10 \mathrm{~m}$ of Hole U1317E. $\mathrm{Ca}^{2+}$ values decrease through underlying Unit M1, reaching a minimum of $8.7 \mathrm{~mm}$ at $\mathrm{ca}$ 130 mbsf. Below this depth, $\mathrm{Ca}^{2+}$ concentrations increase towards an overall maximum of $12.4 \mathrm{~mm}$ at $\mathrm{ca}$ 260 mbsf. $\mathrm{Mg}^{2+}$ concentrations decrease from near sea water values at the top to the base of Site U1317 (Figure $8 \mathrm{~B})$. The degree of decrease with depth is greatest through the mound (Units M2 and M1). Below the mound base, the rate of decrease with increasing depth slows. $\mathrm{Sr}^{2+}$ concentrations show a 10-fold increase, from $c a 212$ to $c a 2300 \mu \mathrm{m}$, from the top of the mound to a depth of $c a 121 \mathrm{mbsf}$ (Figure 8C). This 10 -fold increase occurs over two steps. The first occurs within the upper $10 \mathrm{~m}$ of Unit M2, where concentrations increase from $c a 212$ to $c a 500 \mu \mathrm{m}$ in Hole U1317A and $850 \mu \mathrm{m}$ in Hole U1317E. The second step towards higher concentrations occurs within Unit M1 between 65 and 121 mbsf. Values then decrease downcore to ca $1139 \mu \mathrm{m}$ at 187.54 mbsf. Below this depth, $\mathrm{Sr}^{2+}$ concentrations remain constant.

Sulfate concentrations decrease from near sea water values at the top of the mound to values that approach zero below the base of Challenger Mound at ca 170 mbsf (Figure 8D). Offsets in profiles between Holes U1317A and U1317E show that the degree of decrease with depth through Unit M2 is higher in Hole U1317E. Dissolved methane concentrations (Figure $8 \mathrm{E}$ ) remain $<0.2 \mu \mathrm{m}$ to a depth of 132 mbsf in Hole U1317A and 148 mbsf in Hole U1317D, before increasing downcore to a maximum value of $6660 \mu \mathrm{m}$ at the base of Hole U1317D, (266.01 mbsf). Alkalinity increases downcore from near sea water values at the top of Unit M2 to a maximum of $16.3 \mathrm{~mm}$ at $157.80 \mathrm{mbsf}$ (Fig- 
Table 1. C-O isotope compositions of carbonate components in IODP Holes 1317A, D and E.

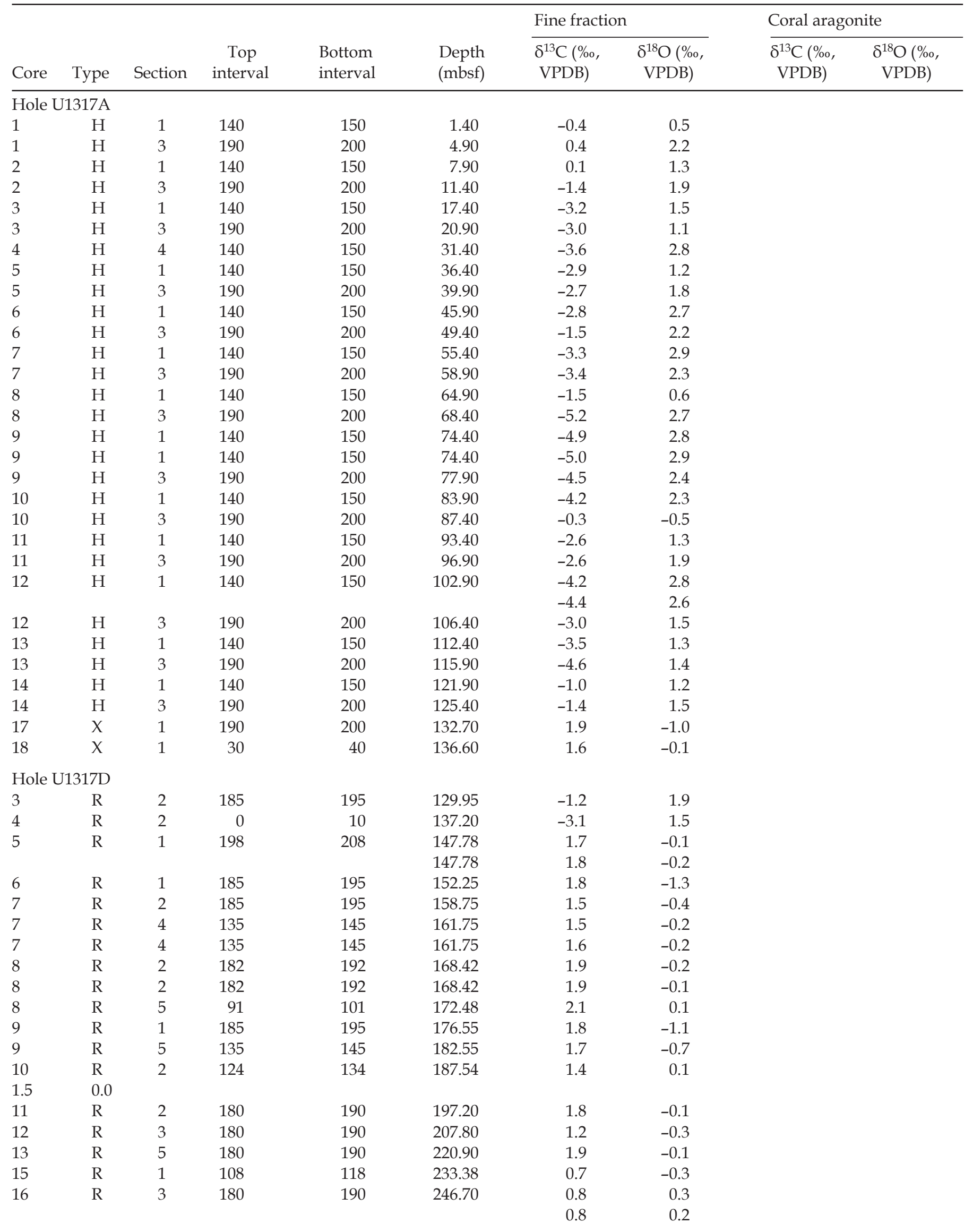


Table 1. C-O isotope compositions of carbonate components in IODP Holes 1317A, D and E (continued).

\begin{tabular}{|c|c|c|c|c|c|c|c|c|c|}
\hline \multirow[b]{2}{*}{ Core } & \multirow[b]{2}{*}{ Type } & \multirow[b]{2}{*}{ Section } & \multirow[b]{2}{*}{$\begin{array}{c}\text { Top } \\
\text { interval }\end{array}$} & \multirow[b]{2}{*}{$\begin{array}{l}\text { Bottom } \\
\text { interval }\end{array}$} & \multirow[b]{2}{*}{$\begin{array}{l}\text { Depth } \\
\text { (mbsf) }\end{array}$} & \multicolumn{2}{|c|}{ Fine fraction } & \multicolumn{2}{|c|}{ Coral aragonite } \\
\hline & & & & & & $\begin{array}{l}\delta^{13} \mathrm{C}(\%, \\
\mathrm{VPDB})\end{array}$ & $\begin{array}{c}\delta^{18} \mathrm{O}(\%, \\
\mathrm{VPDB})\end{array}$ & $\begin{array}{c}\delta^{13} \mathrm{C}(\%, \\
\mathrm{VPDB})\end{array}$ & $\begin{array}{c}\delta^{18} \mathrm{O}(\%, \\
\mathrm{VPDB})\end{array}$ \\
\hline 16 & & & & & & 0.6 & 0.6 & & \\
\hline 17 & $\mathrm{R}$ & 2 & 180 & 190 & 254.80 & 1.4 & 0.0 & & \\
\hline 17 & $\mathrm{R}$ & 4 & 130 & 140 & 257.80 & 1.1 & 0.1 & & \\
\hline 18 & $\mathrm{R}$ & 5 & 0 & 10 & 267.71 & 0.7 & -0.8 & & \\
\hline Hole & \multicolumn{2}{|c|}{ U1317E } & & & & & & & \\
\hline 1 & $\mathrm{H}$ & 1 & 140 & 150 & 1.40 & -1.9 & 0.9 & & \\
\hline 1 & $\mathrm{H}$ & 2 & 68 & 70 & 2.18 & & & -5.1 & 1.1 \\
\hline 1 & $\mathrm{H}$ & 3 & 140 & 150 & 4.40 & -2.7 & 1.8 & & \\
\hline \multirow{2}{*}{1} & & & & & & & & -4.7 & 1.1 \\
\hline & & & & & & & & 0.1 & 2.8 \\
\hline 2 & $\mathrm{H}$ & 2 & 68 & 70 & 8.88 & & & -3.9 & 1.8 \\
\hline 2 & $\mathrm{H}$ & 2 & 140 & 150 & 9.60 & 0.6 & 2.3 & & \\
\hline 2 & $\mathrm{H}$ & 5 & 68 & 70 & 13.38 & & & -1.8 & 1.9 \\
\hline 2 & $\mathrm{H}$ & 5 & 140 & 150 & 14.10 & -0.3 & 2.0 & & \\
\hline 3 & $\mathrm{H}$ & 2 & 68 & 70 & 18.38 & & & -5.0 & 1.1 \\
\hline 3 & $\mathrm{H}$ & 2 & 140 & 150 & 19.10 & -0.4 & 2.6 & & \\
\hline \multirow[t]{2}{*}{3} & $\mathrm{H}$ & 5 & 68 & 70 & 22.88 & & & -4.1 & 0.6 \\
\hline & & & & & & & & -3.9 & 0.8 \\
\hline 3 & $\mathrm{H}$ & 5 & 140 & 150 & 23.60 & 0.3 & -0.8 & & \\
\hline \multirow[t]{2}{*}{6} & $\mathrm{H}$ & 2 & 68 & 70 & 46.88 & & & -3.6 & 1.8 \\
\hline & & 2 & 68 & 70 & 46.88 & & & -3.3 & 2.1 \\
\hline 6 & $\mathrm{H}$ & 5 & 68 & 70 & 51.38 & & & -4.9 & 0.9 \\
\hline 7 & $\mathrm{H}$ & 2 & 75 & 77 & 56.45 & & & -6.6 & 0.5 \\
\hline 7 & $\mathrm{H}$ & 5 & 77 & 78 & 60.97 & & & -7.4 & 0.4 \\
\hline 8 & $\mathrm{H}$ & 2 & 77 & 78 & 65.97 & & & -6.6 & 0.0 \\
\hline 8 & $\mathrm{H}$ & 5 & 77 & 78 & 70.47 & & & -5.2 & 0.3 \\
\hline 9 & $\mathrm{H}$ & 2 & 75 & 76 & 75.45 & & & -6.1 & 0.5 \\
\hline \multirow[t]{2}{*}{9} & $\mathrm{H}$ & 5 & 75 & 76 & 79.95 & & & -7.6 & -0.5 \\
\hline & & & & & & & & -7.6 & -0.5 \\
\hline 10 & $\mathrm{H}$ & 2 & 75 & 76 & 84.95 & & & -6.9 & 0.3 \\
\hline 10 & $\mathrm{H}$ & 2 & 75 & 76 & 84.95 & & & -6.6 & 0.2 \\
\hline 10 & $\mathrm{H}$ & 5 & 77 & 78 & 89.47 & & & -8.4 & -1.7 \\
\hline 11 & $\mathrm{H}$ & 2 & 77 & 78 & 94.47 & & & -5.7 & 0.6 \\
\hline 11 & $\mathrm{H}$ & & & & & & & -4.9 & 0.4 \\
\hline 11 & $\mathrm{H}$ & 5 & 77 & 78 & 99.00 & & & -6.7 & -0.4 \\
\hline 12 & $\mathrm{H}$ & 2 & 77 & 78 & 103.97 & & & -7.4 & 0.3 \\
\hline 12 & $\mathrm{H}$ & 5 & 75 & 76 & 108.45 & & & -8.3 & -0.8 \\
\hline 13 & $\mathrm{H}$ & 2 & 73 & 74 & 113.43 & & & -6.9 & 0.0 \\
\hline 13 & $\mathrm{H}$ & 5 & 75 & 76 & 117.95 & & & -8.6 & -0.6 \\
\hline
\end{tabular}


Table 1. C-O isotope compositions of carbonate components in IODP Holes 1317A, D and E (continued).

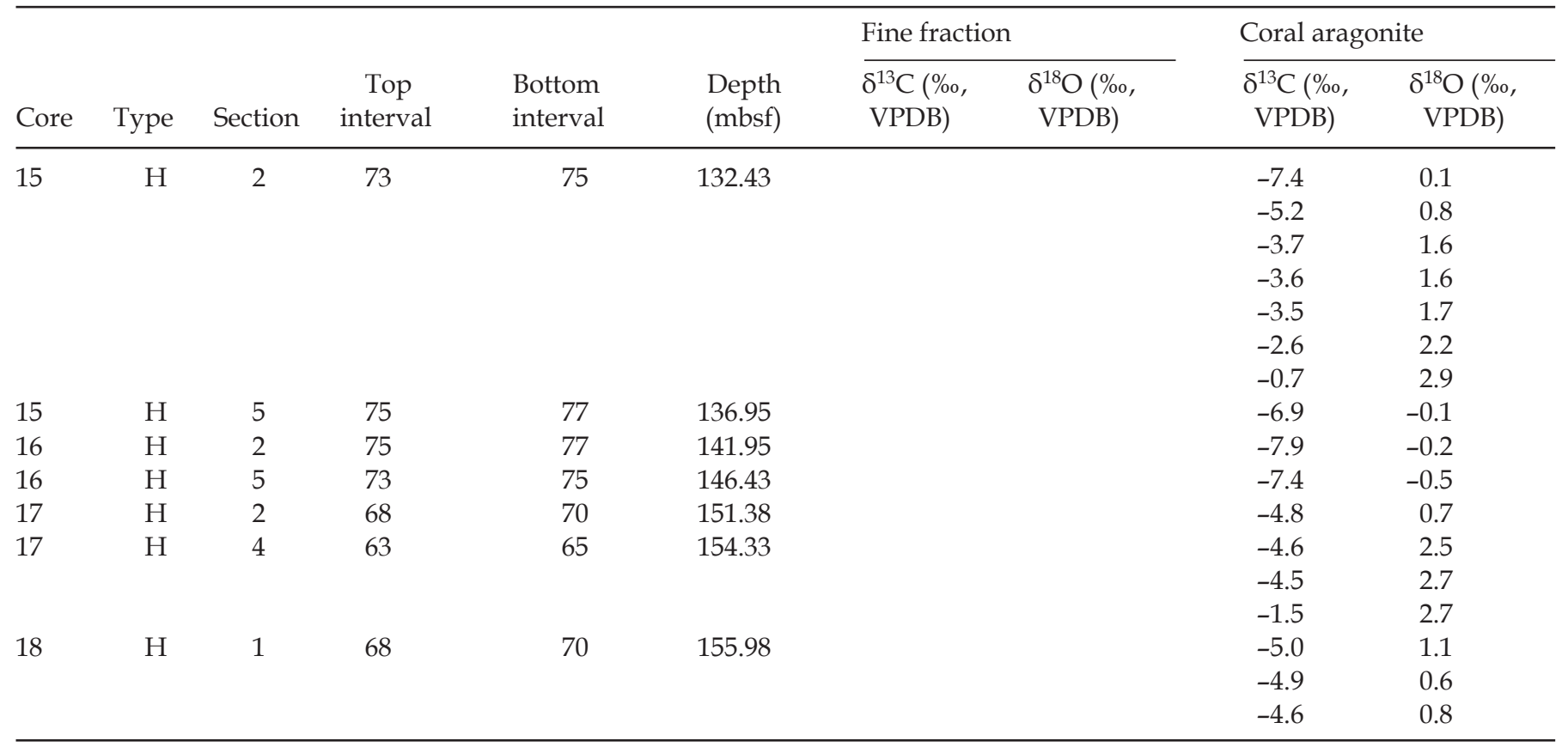

Table 2. $\delta^{13} \mathrm{C}$ values, TOC concentrations and $\mathrm{C} / \mathrm{N}$ ratios of organic matter in Hole U1317E.

\begin{tabular}{|c|c|c|c|c|c|c|c|c|}
\hline Core & Type & Section & Top interval & Bottom interval & Depth (mbsf) & $\delta^{13} \mathrm{C}(\%, \mathrm{VPDB})$ & TOC (wt $\%)$ & $\mathrm{C} / \mathrm{N}$ \\
\hline 2 & $\mathrm{H}$ & 5 & 68 & 70 & 13.38 & -23.1 & 0.5 & 9.0 \\
\hline 3 & $\mathrm{H}$ & 2 & 68 & 70 & 18.38 & -23.2 & 0.4 & 7.9 \\
\hline 4 & $\mathrm{H}$ & 2 & 68 & 70 & 27.88 & -23.0 & 0.5 & 8.0 \\
\hline 5 & $\mathrm{H}$ & 2 & 68 & 70 & 37.38 & -21.7 & 1.0 & 8.8 \\
\hline 6 & $\mathrm{H}$ & 5 & 68 & 70 & 51.38 & -24.3 & 0.6 & 9.1 \\
\hline 8 & $\mathrm{H}$ & 5 & 77 & 78 & 70.47 & -21.7 & 0.6 & 6.7 \\
\hline 9 & $\mathrm{H}$ & 2 & 75 & 76 & 75.45 & -22.9 & 0.5 & 6.6 \\
\hline 9 & $\mathrm{H}$ & 5 & 75 & 76 & 79.95 & -21.9 & 0.5 & 8.2 \\
\hline 10 & $\mathrm{H}$ & 5 & 77 & 78 & 89.47 & -23.9 & 0.2 & 5.0 \\
\hline 11 & $\mathrm{H}$ & 5 & 77 & 78 & 99.00 & -22.4 & 0.6 & 6.7 \\
\hline 13 & $\mathrm{H}$ & 5 & 75 & 76 & 117.95 & -21.2 & 0.7 & 8.6 \\
\hline 15 & $\mathrm{H}$ & 2 & 73 & 75 & 132.43 & -22.5 & 0.5 & 7.4 \\
\hline 15 & $\mathrm{H}$ & 5 & 75 & 77 & 136.95 & -22.1 & 0.3 & 6.5 \\
\hline 16 & $\mathrm{H}$ & 2 & 75 & 77 & 141.95 & -21.7 & 0.8 & 8.3 \\
\hline 16 & $\mathrm{H}$ & 5 & 73 & 75 & 146.43 & -22.9 & 0.2 & 6.1 \\
\hline 17 & $\mathrm{H}$ & 4 & 63 & 65 & 154.33 & -22.0 & 0.5 & 7.2 \\
\hline 18 & $\mathrm{H}$ & 1 & 68 & 70 & 155.98 & -21.7 & 0.9 & 13.6 \\
\hline 18 & $\mathrm{H}$ & 3 & 54 & 56 & 158.84 & -23.5 & 0.8 & 12.8 \\
\hline
\end{tabular}

ure $8 \mathrm{~F}$ ). A comparison of the two profiles through Unit M2 shows that the rate of increase with depth is slightly higher in Hole U1317E (mound apex). Within the Miocene sub-mound section penetrated in Hole U1317D, alkalinity decreases linearly to a minimum of $11.0 \mathrm{~mm}$.

The $\delta^{13} \mathrm{C}$ values of DIC at Site U1317 range from $-8.7 \%$ o to $+3.9 \%$ o (Figure $8 \mathrm{G}$ ). The lowest values oc- 


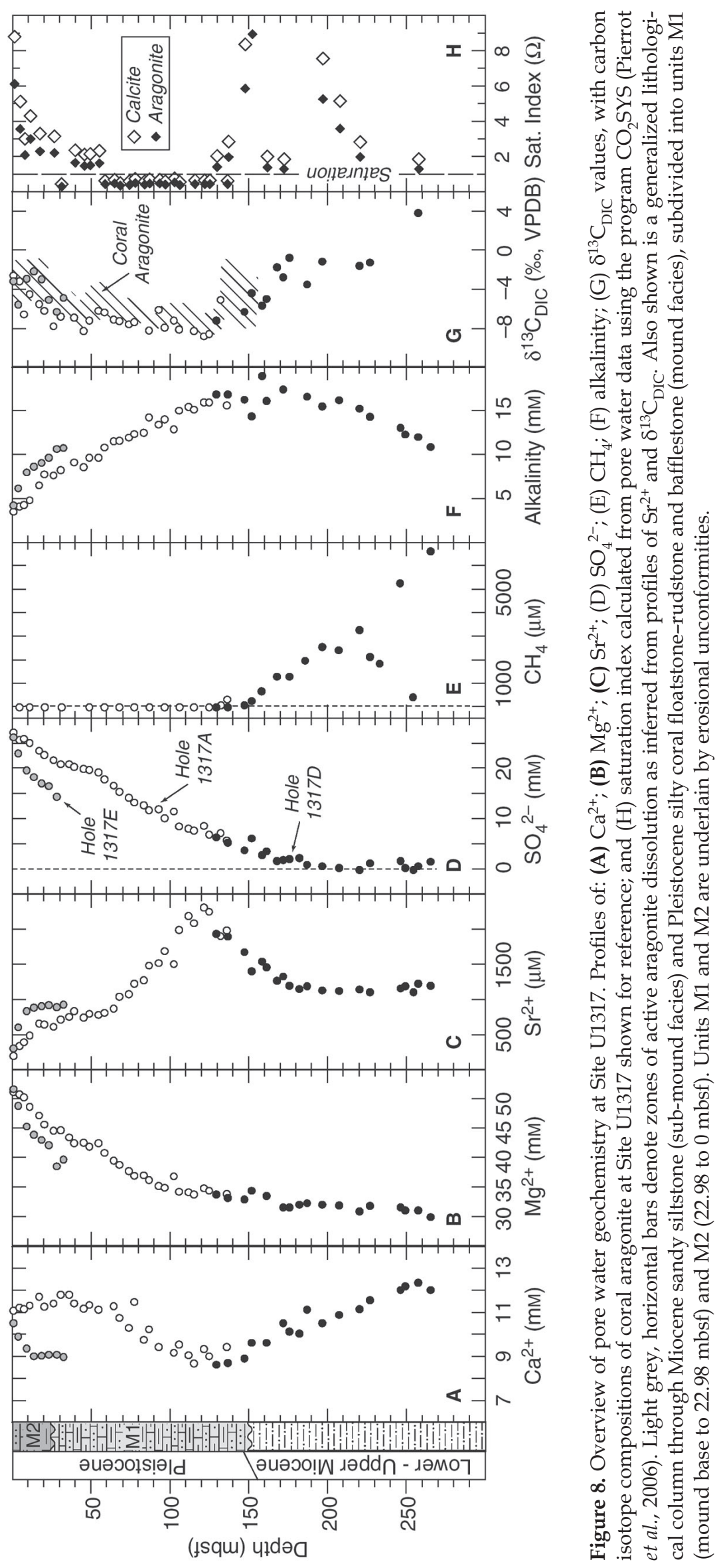


cur through the upper ca $155 \mathrm{~m}$ of Site U1317 (i.e. through the mound facies), with values decreasing from $c a-3 \%$ to $-7 \%$ in the upper $30 \mathrm{~m}$ and remaining relatively uniform below that point $(-7.3 \pm 0.9 \%$ o). Below the mound base, $\delta^{13} \mathrm{C}_{\text {DIC }}$ values increase towards a maximum of $+3.9 \%$ in the lower part of Hole U1317D.

Saturation indices decrease from values of 6 (aragonite) and 9 (calcite), indicating supersaturation, at the top of the mound to values $<1$, indicating undersaturation, by ca 60 mbsf. Indices remain $<1$ for both calcite and aragonite to the base of the mound (Figure $8 \mathrm{H}$ ). Higher values below the mound base indicate that pore water is supersaturated with respect to calcite and aragonite in the Miocene sandy siltstones that underlie the mound.

\section{Discussion}

\section{Mechanisms of aragonite dissolution}

Several early diagenetic processes can lead to the dissolution of calcium carbonate in the upper 10 to $50 \mathrm{~cm}$ of the water column, even in settings where carbonate sediment accumulates well above the aragonite lysocline. Previous work in modern settings, summarized in Mackenzie (2004), points towards three main processes as drivers of dissolution, namely organic matter oxidation, bacterially mediated sulfate reduction and, in Fe-poor settings, sulfide oxidation. During the early stages of organic matter degradation, oxygen serves as the main electron acceptor. When used in the oxidation of organic matter, $\mathrm{CO}_{2}$ is produced, driving down the $\mathrm{pH}$ of the pore water system. At the point when pore waters become undersaturated with respect to calcium carbonate minerals, the $\mathrm{CO}_{2}$ is neutralized by dissolution of $\mathrm{CaCO}_{3}$. The most soluble carbonate phases, aragonite and high-Mg calcite $\left(>12 \mathrm{~mol} \% \mathrm{MgCO}_{3}\right)$, dissolve first, and the process continues until the $\mathrm{CO}_{2}$ is exhausted. This process of 'metabolic dissolution' has been cited as an important mechanism for significant aragonite dissolution in carbonate platform and shelf deposits (Malone et al., 2001; Sanders, 2003; James et al., 2005; Reuning et al., 2006).

Organic-matter oxidation may also take place in concert with bacterially mediated sulfate reduction. During the early stages of sulfate reduction, the $\mathrm{pH}$ drops to a fixed value of ca 6.9 (Ben-Yaakov, 1973), resulting in undersaturation and carbonate dissolu- tion. As sulfate reduction continues, alkalinity gradually rises to a point where, at ca $35 \%$ reduction, the pore water regains supersaturation with respect to calcium carbonate (Morse \& Mackenzie, 1990). This process of aragonite dissolution driven by bacterial oxidation of organic matter using sulfate has been documented in Bahamian platform sediments by Melim et al. (2002).

In shallow-water tropical settings of the platform interior environments of the Bahamas and Florida Bay, a lack of reactive iron has been shown to allow sulfide produced during sulfate reduction to accumulate in solution (Ku et al., 1999; Walter et al., 2007). Oxidation of dissolved sulfide $\left(\mathrm{H}_{2} \mathrm{~S}\right)$ produces $\mathrm{H}^{+}$at a ratio of 1:2 (Boudreau, 1991), leading to a drop in $\mathrm{pH}$ and carbonate dissolution (Ku et al., 1999).

\section{Patterns and mechanisms of aragonite dissolution in Challenger Mound}

\section{Proxy evidence for aragonite dissolution}

In Challenger Mound, the most reliable proxies for aragonite dissolution are petrographic evidence of corrosion and fragmentation (Figures 4 to $7 \mathrm{~A}$ ) and pore water profiles of $\mathrm{Sr}^{2+}$ and $\delta^{13} \mathrm{C}_{\mathrm{DIC}}$ (Figure $8, \mathrm{C} \&$ $\mathrm{G})$. Zones of undersaturation are further constrained by saturation indices for aragonite and calcite that were calculated using pore water geochemical data (Figure 8H).

Examination of corals in thin section revealed that, throughout the mound, these grains are corroded and variably fragmented, consistent with dissolution. Dissolution is fabric-selective and occurs in a step-wise fashion, attacking the least dense areas of the skeleton first. It proceeds first in centers of calcification where the septae and theca meet (PI $=1$ to 2 ) and continues (PI = 2 to 3 ) until these centers are dissolved (Figures $6 \& 7$ ). The relatively dense thecal remnants then undergo dissolution and, ultimately, fragment into sand and silt-sized particles $(\mathrm{PI}=4)$ that continue to dissolve (Figure 4, A, C, \& D). Widespread microboring by sponges and fungi may aid the process of disintegration and dissolution, with unfilled microbores (Figure 6D) and everdecreasing particle size increasing the amount of surface area available for interaction with corrosive pore fluids. Although undergoing corrosion, coral aragonite appears otherwise well-preserved, with no evidence of polymorphic replacement observed. The PI (Figure 7A) reveals that much of the section is characterized by values $>3$, indicating poor to very poor 
preservation. Corals with excellent (0) to good (2) preservation occur mainly in Unit M2 and 100 to $110 \mathrm{mbsf}$ and 130 to 135 mbsf in Unit M1.

Lophelia pertusa skeletons are characterized by high Sr concentrations (8000 to 9000 ppm; Newton et al., 1987; Cohen et al., 2006) compared with average sea water [8.1 ppm $(94 \mu \mathrm{m})]$ and represent the main source of $\mathrm{Sr}$ in Challenger Mound. These factors make pore water $\mathrm{Sr}^{2+}$ profiles highly sensitive indicators of coral dissolution. In Challenger Mound, two excursions towards higher $\mathrm{Sr}^{2+}$ concentrations, indicating the release of $\mathrm{Sr}$ from dissolving coral, are evident in downcore profiles (Figure 8C): (i) within Unit M2, where concentrations increase by a factor of 2 (Hole U1317A) to 5 (Hole U1317E) between the top of the mound and 15 mbsf; and (ii) between 60 and 120 mbsf (lower half of Unit M1), where $\mathrm{Sr}^{2+}$ concentrations increase from $c a 850$ to $2300 \mu \mathrm{m}$ at $120 \mathrm{mbsf}$. The maximum of each excursion is interpreted to mark point sources of $\mathrm{Sr}$, where coral dissolution is relatively intense. The driving mechanisms are discussed below.

Although less-sensitive than pore water $\mathrm{Sr}^{2+}$ profiles, distinct differences in the $\delta^{13} \mathrm{C}$ values of coral aragonite ( $c a-5$ to $-8 \%$ ), sedimentary organic matter $(-22.6 \pm 1.0 \%$ o $)$ and other calcareous components in the sediment matrix $(-2.0 \pm 2.0 \%)$ make downcore profiles of $\delta^{13} C_{\text {DIC }}$ a useful proxy for tracking coral dissolution. The isotopic composition of DIC reflects the balance between contributions from the carbon sources indicated above. Where the pool of DIC is dominated by the products of organic matter oxidation, $\delta^{13} C_{\text {DIC }}$ values should trend towards the composition of sedimentary organic matter. By the same token, values should be similar to those of coral aragonite in zones where coral dissolution is significant. Examination of downcore trends in $\delta^{13} \mathrm{C}$ values of coral aragonite and DIC reveals that these two parameters closely track one another (Figure 8G), indicating that the pool of dissolved carbon in the pore water system is dominated by contributions from coral aragonite. As such, the $\delta^{13} C_{\text {DIC }}$ proxy suggests that coral dissolution is occurring throughout the extent of Challenger Mound.

Saturation indices (Figure $8 \mathrm{H}$ ) indicate that, throughout Unit M2, the pore water is several times supersaturated with respect to both calcite and aragonite. Between 60 and 120 mbsf in Unit M2, indices for both calcite and aragonite are $<1$, indicating that pore waters are corrosive to carbonate through the lower part of the mound.
Considered together, $\mathrm{Sr}^{2+}, \delta^{13} \mathrm{C}_{\mathrm{DIC}}$ and saturation index proxies suggest that, although coral dissolution is occurring throughout Challenger Mound, it is most intense within Unit M2 (0 to $22.98 \mathrm{mbsf}$ ) and in the lower part of Unit M1 (60 to $120 \mathrm{mbsf}$ ).

\section{Aragonite dissolution in unit M2}

Because the mound lies beneath an area of high biological productivity (White et al., 1998, 2005), it is not unreasonable to assume a steady source of organic debris to the sea floor, which could fuel early diagenetic processes including organic matter oxidation and bacterially mediated sulfate reduction. In fact, previous work has shown that cold water coral mounds are effective traps for suspended particulates (marine snow) consisting largely of organic-matter-rich planktonic detritus (Mienis et al., 2007; Titschack et al., 2009), with baffling by the coral framework aided by active catch by corals (Mortensen et al., 2001).

Minimal sulfate reduction in Unit M2 is revealed in the $\mathrm{SO}_{4}{ }^{2-}$ profiles as downcore shifts from about 28 to $20 \mathrm{~mm}$ in Hole U1317A and $15 \mathrm{~mm}$ in Hole U1317E. The $\mathrm{SO}_{4}{ }^{2-}$ profiles indicate that sulfate reduction within Unit M2 is minimal, with the lowest values consistent with ca 29\% (Hole U1317A) and up to $\mathrm{ca} 44 \%$ (Hole U1317E) of available sulfate reduced (Figure 8D). In Hole U1317A, the extent of sulfate reduction lies within the range where undersaturation with respect to aragonite is predicted to result (Morse \& Mackenzie, 1990). In contrast, the more pronounced shift in Hole U1317E exceeds the threshold (35\%) at which the model of Morse \& Mackenzie (1990) predicts that alkalinity generation will drive the system towards calcium carbonate precipitation. Although not observed petrographically, secondary calcite precipitation is consistent with decreasing $\mathrm{Ca}^{2+}$ concentrations and saturation indices $>1$ in the pore water profiles for Hole U1317E (Figure 8, A \& H). Geochemical differences between Holes U1317A and U1317E highlight the effects of small-scale compositional heterogeneities on early diagenetic processes. In the case of Challenger Mound, these differences are interpreted as reflecting more effective baffling of suspended particulates, and hence a greater availability of organic matter to fuel metabolic dissolution and bacterially mediated sulfate reduction at the mound apex relative to the uppermost flanks. 
Aragonite dissolution in unit $M 1$

A second, deeper zone of aragonite dissolution is suggested by the excursion towards higher $\mathrm{Sr}^{2+}$ concentrations at ca $120 \mathrm{mbsf}$ in the lower part of Unit M1 (Figure 8C). This zone of aragonite dissolution overlies a broad zone of sulfate reduction and methane production, as indicated by an increase in dissolved methane (Figure 8E) and a broad peak in alkalinity (Figure $8 \mathrm{~F}$ ) just below the unconformity at the mound base that, in turn, overlies a trend towards zero sulfate reached at $c a 190$ mbsf (Figure 8D). Taking the effects of molecular diffusion, which causes solutes to disperse from sites of higher to lower concentrations, into account, these trends suggest that the zone of anaerobic methane production lies below the depth of coring.

The position of this reaction zone below the upper Miocene to Pleistocene unconformity suggests that it is probably a relatively ancient, perhaps now defunct, one that developed prior to mound growth. Once the mound developed, molecular diffusion of solutes upwards through the pore water system imparted signatures of high alkalinity and dissolved methane and low concentrations of $\mathrm{SO}_{4}{ }^{2-}$ in the lower part of Challenger Mound. Assuming this is the case, aragonite dissolution in Unit M1 could, like its shallow counterpart, be attributed to the presence of undersaturated pore waters produced at greater depths during the early stages of sulfate reduction, which have diffused upwards through the sediment column.

Below the mound base, a return to saturation indices $>1$ (Figure $8 \mathrm{H}$ ) and trends of increasing $\mathrm{Ca}^{2+}$ (Figure 8A) and decreasing $\mathrm{Mg}^{2+}$ (Figure 8B) suggest that, at greater depths, alkalinity generated by sulfate reduction is great enough to drive dolomitization, a process that consumes $\mathrm{Mg}$ and releases $\mathrm{Ca}$ into surrounding pore water (Morrow, 1990). The presence of dolomite below the mound base is confirmed by shipboard observations, including XRD data (Ferdelman et al., 2005).

\section{Summary}

Although observed throughout the mound, proxies for aragonite dissolution point to two zones where corrosion is relatively intense: one within unit M2 and the other in the lower part of unit M1. Although the underlying mechanism appears to be the same in both zones, it is evident from trends in geochemical profiles that corrosive pore waters are being fed into the mound from two directions, above and below, leading to undersaturation through much of the mound interior. Organic matter degradation near the sediment-water interface has more than likely occurred throughout the history of mound development, affecting now-buried paleo-surfaces and probably accounting in part for petrographic evidence of aragonite dissolution in the mound interior (Foubert \& Henriet, 2009).

In contrast, corrosive waters that are diffusing upwards from below the mound base may have reached the lower section of the mound only relatively recently, perhaps slowed by the lower permeability of the sub-mound strata (Ferdelman et al., 2005). Whatever the case, molecular diffusion requires that the undersaturated pore waters continue to disperse away from sites of sulfate reduction and towards the mound interior until uniform conditions are reached. Pore water geochemical profiles therefore suggest that aragonite dissolution should continue for some time.

\section{Predicted diagenetic pathways and products}

The pattern of selective dissolution of aragonitic grains and preservation of calcitic allochems is consistent with the process of 'mineral-controlled' diagenesis that has been documented in many tropical carbonate deposits, as summarized by Lohmann (1988) and James \& Choquette (1990a). In carbonate systems that contain mixtures of aragonite, high-Mg calcite and low-Mg calcite, the differing solubilities of these minerals cause dissolution of the most-soluble phase (aragonite and high-Mg calcite) first, followed by oversaturation with respect to the less-soluble phase (low-Mg calcite) and, ultimately, its precipitation as a secondary phase (cement). Under these conditions, dissolution of low-Mg calcite is prevented because saturation is maintained by dissolution of aragonite. This process, which continues until the available aragonite is exhausted, leads to a change in mineralogy in carbonate sediments, from mixtures of metastable and stable assemblages of carbonate minerals to low-Mg calcite.

The absence of significant secondary calcite in Challenger Mound suggests that oversaturation with respect to calcite via aragonite dissolution has not yet been achieved. Undersaturation is also suggested by calculated saturation indices (Figure $8 \mathrm{H}$ ). Assuming no change in conditions, mineral-controlled diagenesis predicts that coral aragonite will continue to exit the system before Challenger Mound enters the deep burial diagenetic realm. Moreover, the lack of 
infilling of microbores on the surfaces of coral skeletons will prevent the development of micritic envelopes (cf. Bathurst, 1966) that might otherwise preserve evidence in the form of mouldic porosity for the presence of the corals responsible for mound development (Betzler et al., 1997). The resulting loss of diagenetic potential will remove reactive carbonate for later cementation (James \& Bone, 1989) and delay lithification until deeper burial, when the pressure solution-driven process of autolithification (cf. Matter, 1974) takes over. Many of the voids that once contained coral debris (for example, Figure 3D) are expected to be lost through compaction.

\section{Implications for the rock record}

The removal of aragonite has major implications for interpreting the ancient rock record. Perhaps the most obvious consequence is the bias that aragonite loss imparts on grain populations and textures, which could lead to misunderstanding of ecosystems and depositional conditions. For example, some deposits could be mistakenly perceived as accumulations of calcitic assemblages that are considered typical for cool-water carbonate settings (Wright \& Cherns, 2004). In the case of carbonate mounds, a microbial origin might be interpreted erroneously for a muddy deposit with sparse evidence for bafflers or framework builders. A second consequence of aragonite loss is an artificial lowering of apparent rates of sediment accumulation. As pointed out by James et al. (2005), aragonite dissolution may account, at least in part, for the relatively low sedimentation rates calculated for cool-water systems [see compilations in James (1997) and Schlager (2005)].

Some settings may be more prone to early aragonite loss than others. For example, in heterozoandominated systems, which rely on particulate organic matter as a food source, rates of organic matter decomposition at and just below the sediment-water interface might be expected to be higher than that seen in many photozoan-dominated systems that typically form in nutrient-poor settings (Schlager, 2005). In Challenger Mound, efficient trapping of suspended particulate matter (Titschack et al., 2009) would be expected to enrich mound sediments in organic detritus. Rapid degradation of this organic matter could drive early aragonite loss. Removal of organic matter through oxidation could account for minimal sulfate reduction in Challenger Mound. With regard to preservation of grain populations in the geological record, aragonite dissolution might also be expected to be less of an issue in warm tropical settings, where early cementation helps to preserve mouldic porosity by promoting the generation of micritic envelopes around labile grains (Betzler et al., 1997) and strengthening the sediment matrix against compaction (Me$\lim$ et al., 2002).

\section{Conclusions}

Challenger Mound, drilled by Integrated Ocean Drilling Program Expedition 307, provides a unique opportunity to explore mechanisms and implications of aragonite dissolution in carbonate mounds without the complications of later burial alteration. Drilling revealed evidence for widespread dissolution of coral aragonite throughout the mound, which remains virtually unlithified. At or near the sedimentwater interface, oxidation of organic matter drives down the $\mathrm{pH}$ of the pore water system, causing corrosion of coral skeletons while preventing precipitation of secondary calcite. Undersaturation with respect to aragonite and calcite are maintained in the mound interior by the diffusion of corrosive pore waters away from two centers of sulfate reduction, one in the upper $10 \mathrm{~m}$ of the mound section and a second that underlies and pre-dates the mound. The combined effects of decreasing diagenetic potential and loss of reactive carbonate for later cementation will delay lithification until deeper burial, with the onset of autolithification, driven by chemical compaction. Results predict that the final diagenetic product will be a low-porosity body of silty mudstone-wackestone in which fossil evidence of aragonitic coral framework builders is strongly diminished. These processes are expected to leave little trace in the geological record. If it is assumed that similar processes have been active throughout the Phanerozoic, results highlight potential limitations and uncertainties in the ability to reconstruct ancient carbonate systems.

Acknowledgments - This research was supported by a Grant to TDF from JOI-USSAC, administered by U.S. Science Support Program administered by the Joint Oceanographic Institutes (now Ocean Leadership) and a Grant to JT from the priority program SPP527 (IODP/ODP) of the Deutsche Forschungsgemeinschaft (DFG-FR 1134/14-1). We are grateful to members of the Expedition 307 Shipboard Party for assistance with sample collection and scientific discussions. G. Cane (U. Kansas) and D. Dettmann (U. Arizona) are thanked for assistance with isotopic analyses. M. Russell is acknowledged for 
efforts in sample preparation. This project benefited greatly from the expertise of IODP technician D. Graham. Reviews by G. Dix, P. Léonide, and B. Pittet and insights from Associate Editor J. Reijmer led to significant improvements in the article.

\section{References}

Bathurst, R. G. C. (1966) Boring algae, micrite envelopes and lithification of molluscan biosparites. Geol. J., 5(Pt $1), 15-32$.

Ben-Yaakov, S. (1973) pH buffering of pore water of recent anoxic marine sediments. Limnol. Oceanogr., 18, 86-94.

Berger, W. H. (1978) Deep-sea carbonate: Pteropod distribution and the aragonite compensation depth. DeepSea Res., 25, 447.

Betzler, C., Brachert, T. C. and Nebelsick, J. (1997) The warm temperature carbonate province; A review of the facies, zonations, and delimitations. Cour. Forsch.-Inst. Senckenberg, 201, 83-99.

Blamart, D., Rollin-Bard, C., Cuif, J., Juillet-Leclerc, A., Lutringer, A., van Weering, T. C. E., and Henriet, J. (2005) $\mathrm{C}$ and $\mathrm{O}$ isotopes in a deep-sea coral (Lophelia pertusa) related to skeletal microstructure. In: Cold-Water Corals and Ecosystems (eds. A. Freiwald and J. M. Roberts), pp. 1005-1020. Erlangen Earth conference series. Springer-Verlag Berlin Heidelberg, New York, NY.

Boudreau, B. P. (1991) Modelling the sulfide-oxygen reaction and associated $\mathrm{pH}$ gradients in porewaters. Geochim. Cosmochim. Acta, 55, 145-159.

Brachert, T. C., and Dullo, O. (2000) Shallow burial diagenesis of skeletal carbonates; Selective loss of aragonite shell material (Miocene to Recent, Queensland Plateau and Queensland Trough, NE Australia); Implications for shallow cool-water carbonates. Sed. Geol., 136, 169-187.

Cherns, L., and Wright, V. P. (2009) Quantifying the impacts of early diagenetic aragonite dissolution on the fossil record. Palaios, 24, 756-771.

Cohen, A. L., Gaetani, G. A., Lundalv, T., Corliss, B. H., and George, R. Y. (2006) Compositional variability in a coldwater scleractinian, Lophelia pertusa; new insights into 'vital effects'. Geochem. Geophys. Geosyst. G [Super 3], 7, Q12004.

Craig, H. (1957) Isotopic standards for carbon and oxygen and correction factors for mass-spectrometric analysis of carbon dioxide. Geochim. Cosmochim. Acta, 12, 133-149.

De Mol, B., van Rensbergen, P., Pillen, S., van Herreweghe, K., van Rooij, D., McDonnell, A., Huvenne, V., Ivanov, M., Swennen, R., and Henriet, J. P. (2002) Large deepwater coral banks in the Porcupine Basin, southwest of Ireland. Mar. Geol., 188, 193-231.

Ferdelman, T. G., Kano, A., Williams, T., Henriet, J.-P., and the Expedition 307 Scientists (2005) Expedition 307 summary. Proc. IODP, 307, doi:10. 2204/iodp. proc. 307. 101. 2006, pp. 34.

Ferdelman, T. G., Kano, A., Williams, T., and the Expedition 307 Shipboard Party (2006) IODP Expedition 307 drills cold-water coral mound along the Irish continental margin. Sci. Drill., 2, 11-16.

Foubert, A., and Henriet, J. P. (2009) Nature and Significance of the Recent Carbonate Mound Record: The Mound Challenger Code. Lecture Notes in Earth Sciences, 126, Springer-Verlag, Berlin-Heidelberg, $298 \mathrm{pp}$.

Frank, T. D. (2009) Data report: Carbon isotope composition of total dissolved inorganic carbon in interstitial water, Sites U1316, U1317, and U1318, Porcupine Seabight. Proc. IODP, 307, doi: 10. 2204/iodp. proc. 307. 206. 2009, pp. 5.

Freiwald, A., and Roberts, J. M. (2005) Cold Water Corals and Ecosystems. Erlangen Earth Conference Series. Springer-Verlag Berlin Heidelberg, New York, NY, $1243 \mathrm{pp}$.

Gieskes, J. M., Gamo, T., and Brumsack, H. (1991) Chemical methods for interstitial water analysis aboard JOIDES Resolution. ODP Tech. Note, 15, 1-8.

Henriet, J.-P., Guidard, S., and the ODP Proposal 573 Team (2002) Carbonate mounds as a possible example for microbial activity in geological processes. In: Ocean Margin Systems (eds. G. Wefer, D. Billet, D. Hebbeln, B. Joergensen, and T. van Weering), pp. 439-455. SpringerVerlag, Heidelberg.

Huvenne, V. A. I., de Mol, B., and Henriet, J. P. (2003) A 3D seismic study of the morphology and spatial distribution of buried coral banks in the Porcupine Basin, SW of Ireland. Mar. Geol., 198, 5-25.

Huvenne, V. A. I., Van Rooij, D., De Mol, B., Thierens, M., O'Donnell, R., and Foubert, A. (2009) Sediment dynamics and palaeo-environmental context at key stages in the Challenger cold-water coral mound formation: Clues from sediment deposits at the mound base. DeepSea Res. I, 56, 2263-2280.

James, N. P. (1997) The cool-water carbonate depositional realm. Soc. Sed. Geol. Spec. Publ., 56, 1-20.

James, N. P., and Bone, Y. (1989) Petrogenesis of Cenozoic, temperate water calcarenites, South Australia; A model for meteoric/shallow burial diagenesis of shallow water calcite sediments. J. Sed. Petrol., 59, 191-203.

James, N. P., and Choquette, P. W. (1990a) Limestones The meteoric diagenetic environment. In: Diagenesis (eds. I. A. Mcllreath and D. W. Morrow), pp. 13-34. Geoscience Canada Reprint Series 4. Geological Association of Canada: Toronto, ON, Canada.

James, N. P., and Choquette, P. W. (1990b) Limestones - The sea floor diagenetic environment. In: Diagenesis (eds. I. A. Mcllreath and D. W. Morrow), pp. 13-35. Geoscience Canada Reprint Series 4. Geological Association of Canada: Toronto, ON, Canada. 
James, N. P., Bone, Y., and Kyser, K. T. (2005) Where has all the aragonite gone? Mineralogy of Holocene neritic cool-water carbonates, southern Australia. J. Sed. Res., $75,454-463$.

Kano, A., Ferdelman, T. G., Williams, T., Henriet, J.-P., Ishikawa, T., Kawagoe, N., Takashima, C., Kakizaki, Y., Abe, K., Sakai, S., Browning, E. L., Li, X., and IODP Exp. 307 Scientists (2007) Age constraints on the origin and growth history of a deep-water coral mound in the Northeast Atlantic drilled during Integrated Ocean Drilling Program Expedition 307. Geology [Boulder], 35, 1051-1054.

Kenyon, N. H., Akhmetzhanov, A. M., Wheeler, A. J., van Weering, T. C. E., de Haas, H., and Ivanov, M. K. (2003) Giant carbonate mud mounds in the southern Rockall Trough. Mar. Geol., 195, 5-30.

Ku, T. C. W., Walter, L. M., Coleman, M. L., Blake, R. E., and Martini, A. M. (1999) Coupling between sulfur recycling and syndepositional carbonate dissolution; Evidence from oxygen and sulfur isotope composition of pore water sulfate, South Florida Platform, U. S. A. Geochim. Cosmochim. Acta, 63, 2529-2546.

Léonide, P., Floquet, M., and Baudin, F. (2009) Data report: bio- and lithofacies, mineralogy, and organic content of Challenger Mound (Porcupine Seabight, SW Ireland). Proc. IODP, 307, doi: 10. 2204/iodp. proc. 307. 204. 2009, pp. 14.

Lohmann, K. C. (1988) Geochemical patterns of meteoric diagenetic systems and their application to studies of paleokarst. In: Palaeokarst (eds. N. P. James and P. W. Choquette), pp. 58-80. Springer-Verlag, New York, NY.

Mackenzie, F. T. (2004) Sediments, Diagenesis, and Sedimentary Rocks. Treatise on Geochemistry. Elsevier Pergamon, Oxford, UK, 425 pp.

Malone, M. J., Slowey, N. C., and Henderson, G. M. (2001) Early diagenesis of shallow-water periplatform carbonate sediments, leeward margin, Great Bahama Bank (Ocean Drilling Program Leg 166). Geol. Soc. Am. Bull., 113, 881-894.

Manheim, F. T., and Sayles, F. L. (1974) Composition and Origin of Interstitial Waters of Marine Sediments, Based on Deep Sea Drill Cores. John Wiley \& Sons, Inc., New York, 527 pp.

Matter, A. (1974) Burial diagenesis of pelitic and carbonate deep-sea sediments from the Arabian Sea. Init. Rep. Deep Sea Drilling Proj., 23, 421-469.

Melim, L. A., Swart, P. K., and Maliva, R. G. (1995) Meteoric-like fabrics forming in marine waters; Implications for the use of petrography to identify diagenetic environments. Geology [Boulder], 23, 755-758.

Melim, L. A., Westphal, H., Swart, P. K., Eberli, G. P., and Munnecke, A. (2002) Questioning carbonate diagenetic paradigms; Evidence from the Neogene of the Bahamas. Mar. Geol., 185, 27-53.
Meyers, P. A. (1997) Organic geochemical proxies of paleoceanographic, paleolimnologic, and paleoclimatic processes. Org. Geochem., 27, 213-250.

Mienis, F., de Stigter, H. C., White, M., Duineveld, G., de Haas, H., and van Weering, T. C. E. (2007) Hydrodynamic controls on cold-water coral growth and carbonate-mound development at the SW and SE Rockall Trough Margin, NE Atlantic Ocean. Deep-Sea Res. I, 54, 1655-1674.

Morrow, D. W. (1990) Dolomite - Part 2: Dolomitization models and ancient dolostones. In: Diagenesis (eds. I. A. Mcllreath and D. W. Morrow, Amsterdam, The Netherlands), pp. 125-140. Geoscience Canada.

Morse, J. W., and Mackenzie, F. T. (1990) Geochemistry of sedimentary carbonates. Dev. Sedimentol., 48, 707 pp.

Mortensen, P. B. (2001) Aquarium observations on the deepwater coral Lophelia pertusa (L, 1758) (Scleractinia) and selected associated invertebrates. Ophelia. 54, 83-104.

Murray, R. W., Miller, D. J., and Kryc, K. A. (2000) Analysis of major and trace elements in rocks, sediments, and interstitial waters by inductively coupled plasma-atomic emission spectrometry (ICP-AES). ODP Tech. Note, 29, $1-27$.

Newton, C. R., Mullins, H. T., Gardulski, A. G., Hine, A. C., and Dix, G. R. (1987) Coral mounds on the west Florida slope: Unanswered questions regarding the development of deepwater banks. Palaios, 2, 359-367.

Orr, J. C., Fabry, V. J., Aumont, O., Bopp, L., Doney, S. C., Feely, R. A., Gnanadesikano, A., Gruber, N., Ishida, A., Joos, F., Key, R. M., Lindsay, K., Maier-Reimer, E., Matear, R., Monfray, P., Mouchet, A., Najjar, R. G., Plattner, G.-K., Rodgers, K. B., Sabine, C. L., Sarmiento, J. L., Schlitzer, R., Slater, R. D., Totterdell, I. J., Weirig, M.F., Yamanaka, Y., and Yool, A. (2005) Anthropogenic ocean acidification over the twenty-first century and its impact on calcifying organisms. Nature, 437, 681-686.

Pierrot, D., Lewis, E., and Wallace, D. W. R. (2006) MS Excel Program Developed for $\mathrm{CO}_{2}$ System Calculations. ORNL/ CDIAC-105a. Carbon Dioxide Information Analysis Center, Oak Ridge National Laboratory, U. S. Department of Energy, Oak Ridge, TN; http://cdiac. ornl.gov/oceans/co2rprt.html (accessed June 8, 2010).

Reuning, L., Reijmer, J. J. G., and Mattioli, E. (2006) Aragonite cycles: Diagenesis caught in the act. Sedimentology, 53, 849-866.

Sanders, D. (2003) Syndepositional dissolution of calcium carbonate in neritic carbonate environments; Geological recognition, processes, potential significance. J. Afr. Earth Sci. Middle East, 36, 99-134.

Sanders, D. (2004) Potential significance of syndepositional carbonate dissolution for platform banktop aggradation and sediment texture: A graphic modeling approach. Austrian J. Earth Sci., 95/96, 71-79. 
Schlager, W. (2005) Carbonate sedimentology and sequence stratigraphy. Concepts Sedimentol. Paleontol., $8,200 \mathrm{pp}$.

Schwarz, J., and Rendle-Buhring, R. H. (2005) Controls on modern carbonate preservation in the southern Florida Straits. Sed. Geol., 175, 153-167.

Takahashi, T., Williams, R. T., and Bos, D. L. (1982) Carbonate chemistry. In: GEOSECS Pacific Expedition, Volume 3, Hydrographic Data 1973-1974 (eds. W. S. Broecker, D. W. Spencer, and H. Craig), pp. 77-83. National Science Foundation, Washington, DC.

Titschack, J., Thierens, M., Dorschel, B., Schulbert, C., Freiwald, A., Kano, A., Takashima, C., Kawagoe, N., Li, X., and IODP Exp. 307 scientific party (2009) Carbonate budget of a cold-water coral mound (Challenger Mound, IODP Exp. 307). Mar. Geol., 259, 36-46.

Van Rooij, D., de Mol, B., Huvenne, V. A. I., Ivanov, M. K., and Henriet, J. P. (2003) Seismic evidence of currentcontrolled sedimentation in the Belgica mound province, upper Porcupine slope, southwest of Ireland. Mar. Geol., 195, 31-53.

Van Rooij, D., Huvenne, V. A. I., Blamart, D., Henriet, J.P., Wheeler, A. J., and de Haas, H. (2009) The Enya mounds: A lost mound-drift competition. Int. J. Earth Sci. (Geol. Rundsch. ), 98, 849-863.

Van Weering, T. C. E., de Haas, H., de Stigter, H. C., LykkeAndersen, H., and Kouvaev, I. (2003) Structure and development of giant carbonate mounds at the SW and SE Rockall Trough margins, NE Atlantic Ocean. Mar. Geol., 198, 67-81.
Walter, L. M., and Burton, E. A. (1990) Dissolution of Recent platform carbonate sediments in marine pore fluids. Am. J. Sci., 290, 601-643.

Walter, L. M., Bischof, S. A., Patterson, W. P., and Lyons, T. W. (1993) Dissolution and recrystallization in modern shelf carbonates; Evidence from pore water and solid phase chemistry. Philos. Trans. R. Soc. Lond. : Phys. Sci. Eng., 344, 27-36.

Walter, L. M., Ku, T. C. W., Muehlenbachs, K., Patterson, W. P., and Bonnell, L. (2007) Controls on the $\delta^{13} C$ of dissolved inorganic carbon in marine pore waters: An integrated case study of isotope exchange during syndepositional recrystallization of biogenic carbonate sediments (South Florida Platform, USA). Deep Sea Res. I: Top. Stud. Oceanogr., 54, 1163-1200.

White, M., Mohn, C., and Orren, M. J. (1998). ICES Jour. Mar. Sci., 55, 1082-1092.

White, M., Mohn, C., de Stigter, H., and Mottram, G. (2005) Deep-water coral development as a function of hydrodynamics and surface productivity around the submarine banks of the Rockall Trough, NE Atlantic. In: Coldwater Corals and Ecosystems (eds. A. Freiwald and J. M. Roberts), Erlangen Earth Conference Series, pp. 503514. Springer-Verlag Berlin Heidelberg, New York, NY.

Wright, V. P., and Cherns, L. (2004) Are there 'black holes' in carbonate deposystems? Geol. Acta, 2, 285-290.

Wright, V. P., and Cherns, L. (2008) The subtle thief; Selective dissolution of aragonite during shallow burial and the implications for carbonate sedimentology. Soc. Sed. Geol. Spec. Publ., 89, 47-54. 